\title{
Practical application of the wave-trap concept in battery cell equalizers
}

\author{
M. Arias ${ }^{1}$, J. Sebastián ${ }^{1}$, M.M. Hernando ${ }^{1}$, U, Viscarret ${ }^{2}$, I. Gil $^{3}$ \\ ${ }^{1}$-Electronic Power Supply Research Group; University of Oviedo; Campus de Viesques s/n; 33204 SPAIN \\ ${ }^{2}$-Ikerlan; $\mathrm{P}^{\mathrm{o}}$ J. M. Arizmendiarrieta, 20500 Arrasate-Mondragón (Gipuzkoa) \\ ${ }^{3}$-Orona eic s.coop.Elevator Innovation Center; Poligono Epele; 20120 Hernani (Gipuzkoa)
}

mail: ariasmanuel@uniovi.es

\begin{abstract}
The use of battery cell equalizers is mandatory in order to assure that all the cells connected in series are charged to its maximum capacity, even when they present small differences in this parameter due to several factors, such as aging, manufacturing or temperature. Active equalizers, with a higher efficiency in comparison to passive ones, have the disadvantage of using a considerable number of components. Moreover, in the case of active equalizers with very high performance, this number can be even higher. In this paper, the use of the wave-trap concept, widely used in telecommunication systems, is studied. This concept allows the battery cell equalizer to use its switching frequency as the control variable that decides which cell is being charged. Hence, it is not necessary to use a complex system based on a high number of controlled switches in order to determine which cell is being charged. In this way, the number of switches (and the corresponding driving signals) can be strongly minimized without reducing the performance of the system. In order to proof the validity of this concept (i.e., wave traps) in the design of battery-cell equalizers, a topology based on a half-bridge structure is also proposed in this paper. It uses only two controlled switches in order to decide which cell is charged. Experimental results are provided for a 4-cell equalizer as a proof of concept.
\end{abstract}

Keywords: battery, cell, equalizer, balancing, wave trap, frequency.

\section{INTRODUCTION}

Li-ion batteries are widely used nowadays due to their efficient charge and energy density. A battery is formed by cells which are connected in series in order to increase its output voltage and in parallel in order to increase its capacity [1]. Theoretically, these cells should be all equal but, actually, they are not, leading to differences in its capacity and its internal impedance [2]. Their aging is also different, aggravating the problem of their capacity mismatch over time.

In a series connection of several cells (forming a cell pack), these differences in their characteristics may lead to a reduction in the maximum amount of energy that can be stored in the pack. When several Li-ion cells connected in series are charged, none of them may be overcharged due to the risk of premature aging and irreversible deterioration. Therefore, the charging process is finished when any of the cells of the pack is fully charged, making the other cells not being fully charged and reducing the effective overall capacity of the pack [3].

This work has been supported by the Spanish Government under projects CONSOLIDER MICINN-10-CSD2009-00046, ARROWHEAD GA: 332987, and ANRI-DOC (DPI2013-47176-C2-2-R), by European Union under project SPEED (FP7-NMP3-LA-2013-604057) and by IKERLAN and ORONA under project FUO-EM-072-13
Charge equalizers are mandatory in order to assure that all the cells in a series pack are fully charged even when they present differences in their capacity. In this way, the energy stored in the battery is maximized without damaging any of the cells. Equalizers can be classified in passive and active equalizers [4], [5]. The first ones are based in dissipative methods, in which the excess of energy is removed from fully-charged cells while the rest of the cells are still being charged [6], [7]. The cost of this kind of equalizers is the lowest one and the control scheme is simple. Nevertheless, the efficiency is considerably low due to the amount of dissipated energy. Moreover, the number of elements (switches and/or resistors) is not necessarily low.

Active equalizers, on the other hand, present the highest efficiency as they are based on transferring energy from one element (cell pack or most-charged cell) to another element (most discharged cell or cell pack) until all the cells reach the fully-charged state. Actually, some energy is dissipated in the process, but its amount can be neglected in comparison to the amount of energy dissipated in passive equalizers. This transference can be achieved in several ways. One option is using capacitors [7]-[13] or inductors [14]-[19] for storing the energy extracted from one element (e.g., the most-charged cell or the cell pack) and transferring it to another element (e.g., the most-discharged cell). Another option is using converters which directly transfer the energy between cells and balance them [20]-[35]. In all the cases, the number of components is extremely high. Besides, its cost is higher than the cost of passive solutions, and in many cases its control is more complex.

Regarding the number of components, the solutions based on inductors or capacitors need a number of these reactive components similar to the number of cells connected in series [13], [17]. The number of controlled switches is also of that order. It is possible to reduce the number of reactive components to one [10], [22], [36]. In that case, the number of controlled switches has to be increased because the equalizer has to be able to connect the most-charged cell to the reactive component, extract energy from that cell, and then connect the same reactive component to another cell (the most-discharged one). As a consequence, the total number of components (switches plus reactive components) is not actually reduced. In the equalizers based on converters, the total number of components (controlled switches plus diodes plus reactive components) is also high [1], [29]. Using just one converter leads to the aforementioned problem because an additional circuit based on controlled switches need to be 
implemented in order to be able to change the cells which are connected to the output (and in some cases, even to the input) of the converter [3], [20]. As a consequence, the number of controlled switches is not reduced.

In this paper, the use of the wave-trap concept [37] in battery-cell equalizers is proposed and studied. This concept is widely used in telecommunication systems in order to build multiband antennas. The wave traps allow the antenna to disconnect parts of its elements depending on the frequency of the wave. The main purpose of using this concept in equalizers is reducing the number of controlled switches without losing advantages or reducing the performance. Also, in this paper a topology based on a half-bridge structure is proposed as a proof of concept. In order to decide which cell is going to be charged, this equalizer does not use a complex system with a high number of controlled switches. The wave-trap concept is employed instead [37]. The cell to be charged by the equalizer is determined by the switching frequency of the converter and, as a consequence, the total number of controlled switches is just two (those of the half-bridge structure). This also strongly reduces the complexity of the control scheme (e.g., there is no need of controlling a high number of MOSFETs referred to a floating voltage).

The switching frequency being the control variable that decides which cell is charged by the equalizer may imply a limited number of cells for a given switching frequency range, especially if tolerances in the components are taken into account. As will be explained, the use of the wave-trap concept alleviates this problem as it allows the system to increase the number of cells for a given switching frequency range due to the high selectivity of the traps.

The accuracy of the proposed system is high, so each cell can be precisely charged. It should be said that it is possible to reduce the number of controlled switches in an equalizer as proposed in [21], in which a multi-output Flyback is used. The main drawback is that the system does not actively control the cell that is charged. It depends on the voltage of all the cells and, also, on the

Table 1. Comparative of several battery cell equalizers.

\begin{tabular}{|c|c|c|c|c|c|c|c|c|}
\hline & Resistors & Magnetics & Capacitors $^{1}$ & Diodes & MOSFETs & Speed $^{2}$ & Efficiency $^{3}$ & $\begin{array}{c}\text { Control } \\
\text { simplicity and } \\
\text { performance }^{4}\end{array}$ \\
\hline Dissipative [4], [6] & $\mathrm{n}$ & 0 & 0 & 0 & $\mathrm{n}$ & $\mathrm{L}$ & $\mathrm{L}$ & $\mathrm{H}$ \\
\hline $\begin{array}{c}\text { Switched capacitors } \\
{[8]}\end{array}$ & 0 & 0 & $\mathrm{n}-1$ & 0 & $2 \cdot n$ & $\mathrm{~L}$ & M & M \\
\hline $\begin{array}{l}\text { Single Switched } \\
\text { capacitor [5], [10] }\end{array}$ & 0 & 0 & 1 & 0 & $2 \cdot(n+1)+4$ & $\mathrm{~L}$ & M & $\mathrm{L}$ \\
\hline $\begin{array}{c}\text { Double-Tiered } \\
\text { Switched capacitors } \\
{[11]}\end{array}$ & 0 & 0 & $2 \cdot n-3$ & 0 & $2 \cdot n$ & M & M & M \\
\hline $\begin{array}{c}\text { Zero-Current- } \\
\text { Switching switched } \\
\text { Capacitors [13] }\end{array}$ & 0 & $\mathrm{n}-1$ inductors & $\mathrm{n}-1$ & 0 & $2 \cdot n$ & $\mathrm{~L}$ & $\mathrm{H}$ & M \\
\hline $\begin{array}{l}\text { Buck-Boost (single } \\
\text { inductor) [14] }\end{array}$ & 0 & 1 inductor & 0 & $2 \cdot n$ & $2 \cdot n$ & M & $\mathrm{H}$ & $\mathrm{L}$ \\
\hline $\begin{array}{c}\text { Buck-Boost } \\
\text { (multiple inductors) } \\
{[15],[16]}\end{array}$ & 0 & $\mathrm{n}-1$ inductors & $\mathrm{n}$ & $2 \cdot(n-1)$ & $2 \cdot(n-1)$ & M & M & M \\
\hline $\begin{array}{c}\text { Buck-Boost } \\
\text { (multiple coupled } \\
\text { inductors) [16] }\end{array}$ & 0 & $\begin{array}{l}2 \cdot(n-1) \text { inductors } \\
\text { (using } n-1 \text { cores) }\end{array}$ & n (optional) & $4 \cdot(n-1)$ & $4 \cdot(n-1)$ & M & M & M \\
\hline $\begin{array}{c}\text { Selective Flyback } \\
{[20]}\end{array}$ & 0 & $\begin{array}{c}1 \text { transformer } \\
\text { (1 secondary winding) }\end{array}$ & 1 & $2 \cdot(n-1)+1$ & $2 \cdot n$ & M & M & $\mathrm{L}$ \\
\hline $\begin{array}{l}\text { Multi-output } \\
\text { Flyback [21] }\end{array}$ & 0 & $\begin{array}{c}1 \text { transformer } \\
\text { (n secondary windings) }\end{array}$ & $\mathrm{n}$ & $\mathrm{n}$ & 1 & $\mathrm{H}$ & M & $\mathrm{L}$ \\
\hline $\begin{array}{c}\text { Modular } \\
\text { (m intramodules) } \\
{[25]}\end{array}$ & 0 & $\mathrm{~m}+\mathrm{n}$ transformers & 0 & $\mathrm{n}$ & $m+2 \cdot n$ & M & $\mathrm{H}$ & $\mathrm{L}$ \\
\hline $\begin{array}{c}\text { Multiwinding } \\
\text { transformer [26] }\end{array}$ & 0 & $\begin{array}{c}1 \text { transformer } \\
\text { ( } \mathrm{n} \text { windings) } \\
\mathrm{n} \text { inductors }\end{array}$ & $2 \cdot n$ & 0 & $\mathrm{n}$ & M & $\mathrm{H}$ & $\mathrm{L}$ \\
\hline $\begin{array}{c}\text { Bidirectional } \\
\text { Flyback [1], [28] }\end{array}$ & 0 & $\mathrm{n}$ transformers & $\mathrm{n}$ & 0 & $2 \cdot n$ & $\mathrm{H}$ & $\mathrm{H}$ & M \\
\hline $\begin{array}{l}\text { Modular two stages } \\
\text { (m modules) [3] }\end{array}$ & 0 & $\mathrm{~m}+1$ transformers & 1 & $\mathrm{~m}+1$ & $4 \cdot(n-1)+(m+1)$ & $\mathrm{H}$ & $\mathrm{H}$ & $\mathrm{L}$ \\
\hline Class-E & 0 & $\begin{array}{c}1 \text { transformer } \\
(\mathrm{n} / 2 \text { secondary windings) }\end{array}$ & $\mathrm{n}+1$ & $\mathrm{n}$ & 1 & $\mathrm{H}$ & $\mathrm{H}$ & M \\
\hline $\begin{array}{l}\text { Proposed (wave trap } \\
\text { concept) }\end{array}$ & 0 & $\begin{array}{c}\mathrm{n} \text { inductors } \\
\text { (1 secondary winding) }\end{array}$ & $\mathrm{n}$ & $\mathrm{n}$ & 2 & M & M & M \\
\hline
\end{tabular}

=Low;M=Medium;H=High

1- Smoothing capacitors are included when necessary.

2-Speed is evaluated according to the number of cells that can be equalized at the same time, the amount of energy transferred, the number of cells involved in the energy transmission, etc.

3- Efficiency is evaluated according to the number of elements that have to drive the equalizing current, the efficiency of each stage, etc.

4-Control includes both the precision that can be achieved in the equalization and its simplicity. It is evaluated according to the number of control signals, the easiness of generating them, the possibility of choosing the cell that is being charged, the necessity of sensing the voltage of all the cells, etc. 
leakage inductance of each output (something not totally under control). As a consequence, although several cells can be balanced at the same time, a voltage imbalance may appear [4]. With the wave-trap concept, the leakage inductance of the magnetic components is not a problem as the system may actively decide which cell is charged in each moment depending on the switching frequency of the half-bridge structure.

The purpose of this paper is analyzing the feasibility of the wave-trap concept rather than presenting a specific equalizer topology. Nevertheless, it may be interesting to include a comparative study of different topologies including the one proposed in this paper as a proof of concept (it will be explained in section III). This comparison is presented in Table 1.

This paper is organized as follows. A brief description of the proposed concept is provided in section II. A deep insight of the topology is given in section III. The design guideline resulting from the previous sections is explained in section IV. Finally, the experimental results are shown in section $\mathrm{V}$ and the conclusions are gathered in section VI.

\section{BRIEF DESCRIPTION OF THE PROPOSED CONCEPT}

The wave-trap concept is going to be used in this application for selecting the cell that is going to be charged by the proposed equalization system. In Fig. 1a, a string of $\mathrm{n}$ traps is presented. Each trap consists of a capacitor and an inductor connected in parallel. Therefore, the impedance of each trap is:

$$
Z_{i}(\omega)=\frac{j \cdot \omega L_{i}}{1-\omega^{2} \cdot L_{i} \cdot C_{i}}
$$

where $\mathrm{Z}_{\mathrm{i}}(\omega)$ is the impedance of trap $\mathrm{i}$ for the pulsation $\omega$, and $\mathrm{L}_{\mathrm{i}}$ and $\mathrm{C}_{\mathrm{i}}$ are the inductance and the capacitance of the inductor and the capacitor used in the trap. As can be seen, each trap has one zero, which introduces a $+20 \mathrm{~dB} / \mathrm{dec}$, and two poles, located at the same frequency, which lead to a $-20 \mathrm{~dB} / \mathrm{dec}$ slope after the resonant frequency $\mathrm{f}_{\mathrm{i}}$, which is:

$$
\mathrm{f}_{\mathrm{i}}=\frac{1}{2 \cdot \pi \cdot \sqrt{\mathrm{L}_{\mathrm{i}} \cdot \mathrm{C}_{\mathrm{i}}}} .
$$

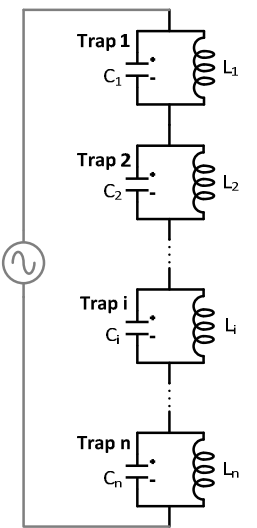

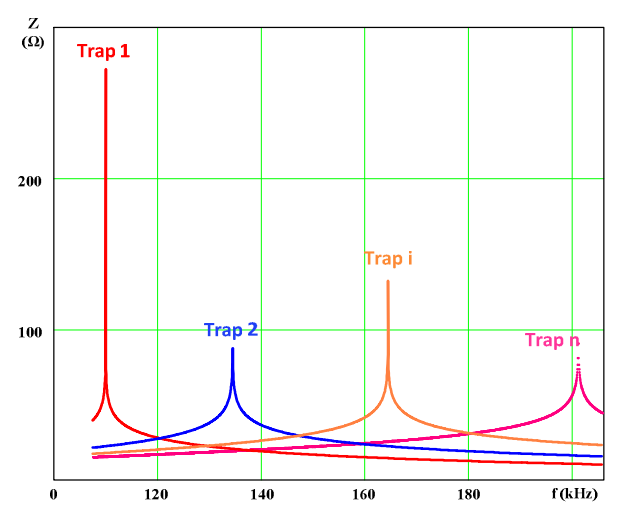

b)

Fig. 1. a) String of $n$ traps (in grey, a sinusoidal voltage source); b) Impedance of the $\mathrm{n}$ traps as a function of the frequency of the sinusoidal voltage applied to the string.
Each trap is designed so that its resonant frequency is different from the resonant frequencies of the other traps (Fig. 1b). If this string of traps is supplied with a sinusoidal voltage whose frequency is equal to the resonant frequency of one of the traps, according to (1) its impedance will be considerably higher than the impedance of the other traps (Fig. 1b). Consequently, nearly all the voltage applied to the string will be withstood by this trap, while the others will only withstand a voltage close to zero due to their low impedance at that frequency.

It is possible to take advantage of this concept and use it for a battery equalizer by employing a circuit as the one proposed in Fig. 2a. As can be seen, a half-bridge structure is connected to the string of traps and will be in charge of providing the required voltage to it. In the traps, the inductors have been replaced with transformers. That is mandatory due to the series connection of the battery cells, which implies that the output of each trap has to be isolated. The resonant frequency of each trap in then defined by the capacitor and the magnetizing inductance of the transformer (neglecting its leakage inductance due to its low value). The use of transformers also makes possible to supply the half-bridge structure with the voltage of the whole cell pack (i.e., the battery). Hence, the proposed equalization system extracts energy from the whole battery and supplies it to the most-discharged cell.

As can be easily seen, the frequency of the voltage applied to the string of traps is the switching frequency of the half-bridge structure. Therefore, this switching frequency is the control variable that defines which trap is chosen. In other words, it defines which trap is going to withstand nearly all the voltage applied to the whole string. This voltage is going to be reflected to the secondary side of the transformer and can be then used to charge the cell connected to it. It only has to be high enough to directly bias the rectifier diode. In fact, depending on the amplitude of this voltage, the equalization current of the cell can be controlled (this will be deeply explained in the next section). The other cells of the battery are not undesirably charged by the proposed system because the corresponding rectifier diodes are reverse biased due to the low value of the voltage withstood by the corresponding traps.

\section{ANALYSIS OF THE TOPOLOGY}

First of all, it should be taken into account that the voltage provided by the half-bridge structure $\left(\mathrm{V}_{\mathrm{HB}}\right.$ in Fig. 2a) is not a sinusoidal waveform (as in Fig. 1a), but a square one. In order to have almost-sinusoidal waveforms across the traps, an additional inductor $\mathrm{L}_{\mathrm{H}}$ has been included (see Fig. 2a). This inductor (and the traps behaving as an inductor) will withstand the voltage harmonics above the switching frequency and, therefore, the chosen trap (i.e., the trap whose resonant frequency coincides with the switching frequency) will withstand an almost-sinusoidal voltage. Therefore, for the sake of simplicity in the analysis of the topology, only the first harmonic component of the voltage provided by the halfbridge structure $\left(\mathrm{V}_{\mathrm{HB} \text { h1 }}\right.$ in Fig. $\left.2 \mathrm{~b}\right)$ will be considered. This is a similar approach to the one used in the analysis of resonant converters [38]-[40]. 
The driving scheme of the MOSFETs of the halfbridge structure is the asymmetrical one [41]-[48]. The reason for choosing this scheme (and not the morecommon symmetrical one) is explained later in this section. In this driving scheme, the control signals of the MOSFETs are complementary. Hence, if D is the duty cycle of MOSFET 1 , then the duty cycle of MOSFET 2 is (1-D). This also means that one of them is always turned on. As the volt-second balance in the inductive components has to be maintained, the voltages of the input capacitors of the half-bridge structure satisfy [43]:

$$
\mathrm{V}_{\mathrm{Cin}_{-} 1}=(1-\mathrm{D}) \cdot \mathrm{V}_{\text {in }}=(1-\mathrm{D}) \cdot \mathrm{V}_{\text {bat }} \text {, }
$$

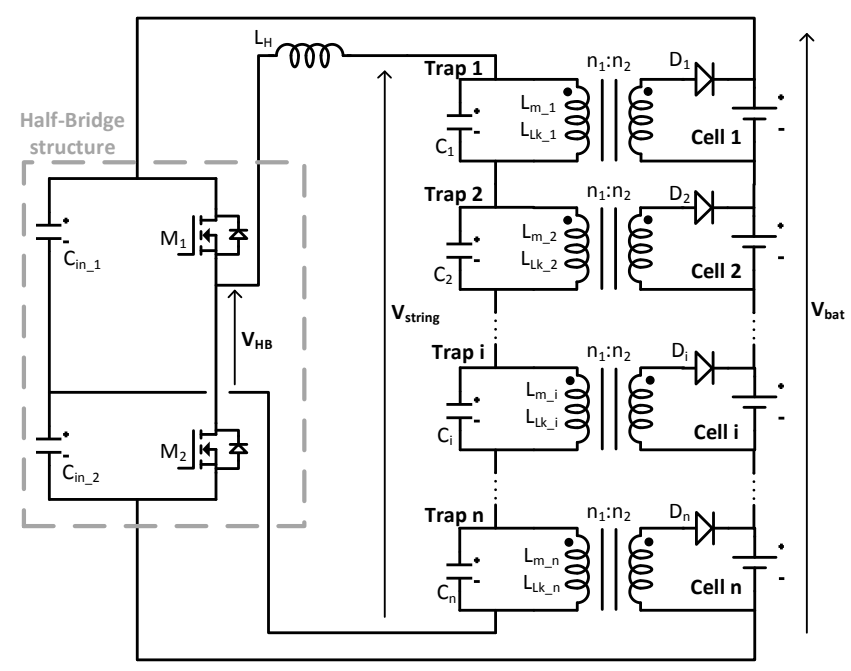

a)

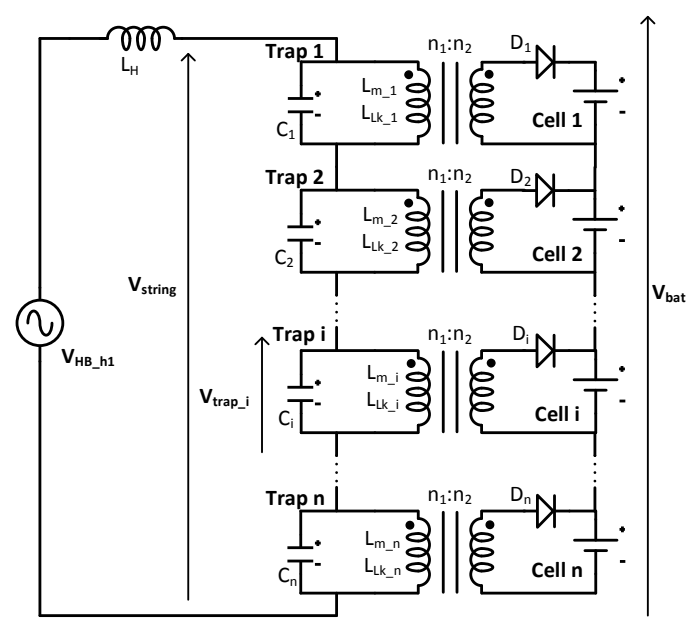

b)

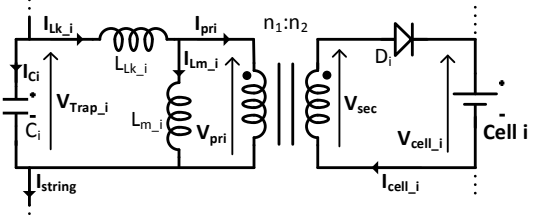

c)

Fig. 2. a) Scheme of the proposed battery equalizer; b) Equivalent circuit ; c) Detail of trap i including the leakage and the magnetizing inductances of the transformer.

$$
\mathrm{V}_{\mathrm{Cin}_{-} 2}=\mathrm{D} \cdot \mathrm{V}_{\text {in }}=\mathrm{D} \cdot \mathrm{V}_{\text {bat }} \text {, }
$$

where $\mathrm{V}_{\mathrm{Cin} \_1}$ and $\mathrm{V}_{\mathrm{Cin} \_2}$ are the voltages of the input capacitors $\bar{C}_{\mathrm{in}_{\_} 1}$ and $\mathrm{C}_{\mathrm{in} \_2}$, and $\mathrm{V}_{\mathrm{in}}$ is the input voltage of the half-bridge structure (equal to the battery voltage $\mathrm{V}_{\mathrm{bat}}$ ). These voltages define the voltage $\mathrm{V}_{\mathrm{HB}}(\mathrm{t})$ as can be seen in Fig. 3a. The Fourier analysis of this waveform leads to the following equation:

$$
\begin{aligned}
\mathrm{V}_{\mathrm{HB}_{-} \mathrm{hk}}(\mathrm{t})= & \frac{\mathrm{V}_{\text {in }}}{\pi \cdot \mathrm{k}}\left[\sin (2 \cdot \pi \cdot \mathrm{k} \cdot \mathrm{D}) \cdot \cos \left(2 \cdot \pi \cdot \mathrm{f}_{\mathrm{sw}} \cdot \mathrm{k} \cdot \mathrm{t}\right)+\right. \\
& \left.+(1-\cos (2 \cdot \pi \cdot \mathrm{k} \cdot \mathrm{D})) \cdot \sin \left(2 \cdot \pi \cdot \mathrm{f}_{\mathrm{sw}} \cdot \mathrm{k} \cdot \mathrm{t}\right)\right],
\end{aligned}
$$

where $\mathrm{v}_{\mathrm{HB}_{-} \mathrm{hk}}(\mathrm{t})$ is the $\mathrm{k}^{\text {th }}$ harmonic component of the voltage $v_{\mathrm{HB}}(t)$ and $\mathrm{f}_{\mathrm{sw}}$ is the switching frequency of the half-bridge structure. Therefore, the first harmonic component satisfies:

$$
\begin{aligned}
\mathrm{V}_{\mathrm{HB}_{-} \mathrm{h} 1}(\mathrm{t})= & \frac{\mathrm{V}_{\text {in }}}{\pi} \cdot\left[\sin (2 \cdot \pi \cdot \mathrm{D}) \cdot \cos \left(2 \cdot \pi \cdot \mathrm{f}_{\mathrm{sw}} \cdot \mathrm{t}\right)+\right. \\
& \left.+(1-\cos (2 \cdot \pi \cdot \mathrm{D})) \cdot \sin \left(2 \cdot \pi \cdot \mathrm{f}_{\mathrm{sw}} \cdot \mathrm{t}\right)\right] .
\end{aligned}
$$

This equation can be rewritten as:

$$
\mathrm{V}_{\mathrm{HB}_{-} \mathrm{h} 1}(\mathrm{t})=\mathrm{A}_{\mathrm{h} 1}\left(\mathrm{D}, \mathrm{V}_{\mathrm{in}}\right) \cdot \sin \left(2 \cdot \pi \cdot \mathrm{f}_{\mathrm{sw}} \cdot \mathrm{t}+\Phi_{\mathrm{sw}}\right) \text {, }
$$

where:

$$
\begin{gathered}
\mathrm{A}_{\mathrm{h} 1}\left(\mathrm{D}, \mathrm{V}_{\mathrm{in}}\right)=\frac{2 \cdot \mathrm{V}_{\mathrm{in}}}{\pi} \cdot \sin (\pi \cdot \mathrm{D}) \\
\Phi_{\mathrm{sw}}=\pi \cdot\left(\frac{1-2 \cdot \mathrm{D}}{2}\right)
\end{gathered}
$$

This first harmonic component has been represented in Fig. 3a for the depicted square-waveform voltage $\mathrm{v}_{\mathrm{HB}}(\mathrm{t})$.

It should be noted that the half-bridge structure will always operate with a switching frequency $f_{s w}$ equal to the resonant frequency $f_{i}$ of one of the traps (the one connected to the most-discharged cell):

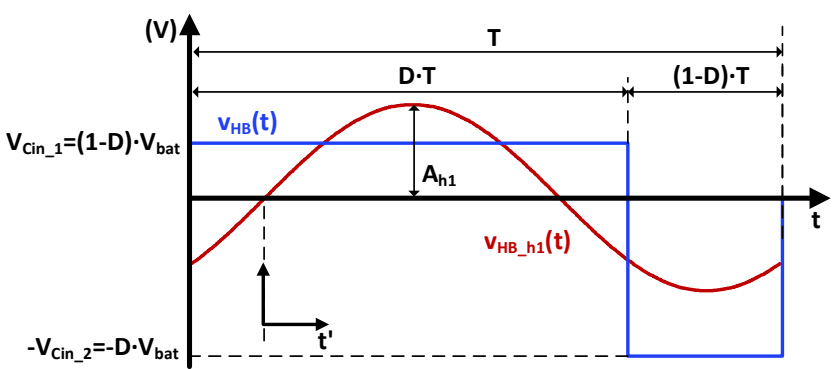

a)

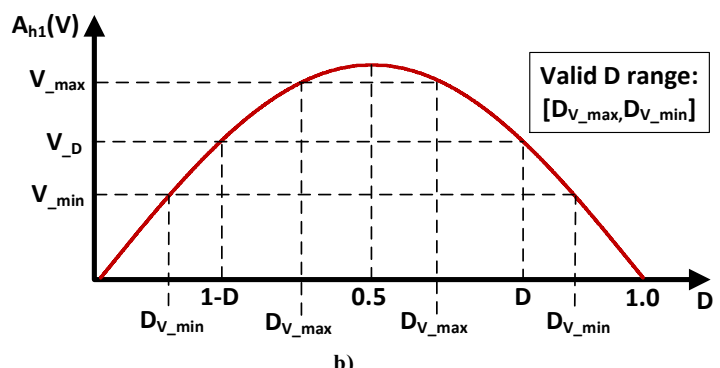

Fig. 3. a) Waveform of $\mathrm{v}_{\mathrm{HB}}(\mathrm{t})$ and its first harmonic component $\mathrm{v}_{\mathrm{HB} \_\mathrm{h} 1}(\mathrm{t})$; b) Amplitude of $\mathrm{v}_{\mathrm{HB} \_\mathrm{h} 1}(\mathrm{t})$ for different duty cycles. 


$$
\mathrm{v}_{\mathrm{HB}_{-} \mathrm{h} 1}(\mathrm{t})=\mathrm{A}_{\mathrm{h} 1}\left(\mathrm{D}, \mathrm{V}_{\mathrm{in}}\right) \cdot \sin \left(2 \cdot \pi \cdot \mathrm{f}_{\mathrm{i}} \cdot \mathrm{t}+\Phi_{\mathrm{sw}}\right) \text {. }
$$

The impedance corresponding to the non-chosen traps is very low. The impedance of $L_{H}$ at any $f_{i}$ is also quite low. Due to this, the voltage withstood by the chosen trap $\mathrm{V}_{\text {Trap_i }}(\mathrm{t})$ can be approached by $\mathrm{V}_{\mathrm{HB} \_\mathrm{h} 1}(\mathrm{t})$ :

$$
\mathrm{v}_{\text {Trap }_{-} \mathrm{i}}(\mathrm{t}) \approx \mathrm{V}_{\mathrm{HB}_{-} \mathrm{h} 1}(\mathrm{t})=\mathrm{A}_{\mathrm{h} 1}\left(\mathrm{D}, \mathrm{V}_{\mathrm{in}}\right) \cdot \sin \left(2 \cdot \pi \cdot \mathrm{f}_{\mathrm{i}} \cdot \mathrm{t}+\Phi_{\mathrm{i}}\right) \text {. }
$$

Equations (8) and (11) show that the amplitude of $\mathrm{V}_{\text {Trap } \mathrm{i}}(\mathrm{t})$ can be controlled by means of the duty cycle $\mathrm{D}$. This is the reason for using the asymmetrical driving scheme. In Fig. 3b, the amplitude of $\mathrm{v}_{\text {Trap }} \mathrm{i}(\mathrm{t})$ as a function of $\mathrm{D}$ is represented. As can be seen, duty cycles between 0 and 0.5 provide the same voltage amplitude as the corresponding duty cycles in the range between 0.5 and 1.0. Hence, only one of these two ranges should be used. As shown in Fig. 3b, the operating range of $\mathrm{D}$ will be defined by $\mathrm{D}_{\mathrm{V}_{\text {min }}}$ and $\mathrm{D}_{\mathrm{V}_{\text {max }}}$, being $\mathrm{D}_{\mathrm{V}_{\text {min }}}$ the duty cycle which provides the lowest amplitude and $\mathrm{D}_{\mathrm{V}_{\text {max }}}$ the one which provides the highest one. In this paper, D will be located in the 0.5-1.0 range (see Fig. 3b).

The chosen trap shown in Fig. $2 \mathrm{c}$ has been redrawn in Fig. 4a. In this figure, the capacitor $C_{i}$ has been replaced with the voltage source $\mathrm{v}_{\text {Trap_i }}(\mathrm{t})$ due to the high quality factor of the filter that each trap represents. It should be noted that this high quality factor is needed for the proper operation of the proposed system. The behaviour of the trap will change depending on whether the diode is reverse biased or not. When it is reverse biased, the valid circuit is the one presented in Fig. 4b. Nevertheless, if the voltage withstood by the trap reaches a value high enough, the diode will be directly biased and the trap will behave as the circuit presented in Fig. 4c. Analysing these two circuits it is possible to calculate the electric charge that the trap transfers to the cell in each switching period and, therefore, the amount of energy transferred. For this analysis, the following assumptions are made:

- The equivalent capacity of the cell is very high. Therefore, it can be considered as a constant voltage source in each switching period.

- The value of the current through $\mathrm{L}_{\mathrm{H}}$ is much lower than the resonant current passing through the inductor and the capacitor of the chosen trap. This is due to the aforementioned high quality factor of the traps.

- The diode conduction time is considerably shorter than the resonant period. This is due to the fact that the diode will conduct only when the voltage in the secondary side of the transformer is positive and high enough.

- For the sake of clarity, in the next explanation $\mathrm{v}_{\text {Trap_i }}(\mathrm{t})$ will be referred to $\mathrm{t}$ ', a different time reference shown in Fig. 3a. Hence, equation (11) can be rewritten as:

$$
\mathrm{v}_{\text {Trap_i }}\left(\mathrm{t}^{\prime}\right)=\mathrm{A}_{\mathrm{h} 1}\left(\mathrm{D}, \mathrm{V}_{\mathrm{in}}\right) \cdot \sin \left(2 \cdot \pi \cdot \mathrm{f}_{\mathrm{i}} \cdot \mathrm{t}^{\prime}\right) \text {, }
$$

where t' is:

$$
\mathrm{t}^{\prime}=\mathrm{t}+\frac{\Phi_{\mathrm{i}}}{2 \cdot \pi \cdot \mathrm{f}_{\mathrm{i}}}
$$

When the diode is not directly biased (Fig. 4b), the current through the magnetizing inductance is equal to the current through the leakage inductance. This current can be calculated using the sinusoidal steady-state phasor analysis because the diode conduction time is much shorter that the resonant period (as already mentioned). Therefore:

$$
\begin{aligned}
\mathrm{i}_{\mathrm{Lm}_{-} \mathrm{i}}\left(\mathrm{t}^{\prime}\right) & =\mathrm{i}_{\mathrm{Lk}_{-} \mathrm{i}}\left(\mathrm{t}^{\prime}\right)=\frac{\mathrm{v}_{\text {Trap }_{-} \mathrm{i}}\left(\mathrm{t}^{\prime}\right)}{\mathrm{j} \cdot 2 \cdot \pi \cdot \mathrm{f}_{\mathrm{i}} \cdot \mathrm{L}_{\mathrm{i}}}= \\
& =\frac{1}{2 \cdot \pi \cdot \mathrm{f}_{\mathrm{i}} \cdot \mathrm{L}_{\mathrm{i}}} \cdot \mathrm{A}_{\mathrm{h} 1}\left(\mathrm{D}, \mathrm{V}_{\mathrm{in}}\right) \cdot \sin \left(2 \cdot \pi \cdot \mathrm{f}_{\mathrm{i}} \cdot \mathrm{t}^{\prime}-\frac{\pi}{2}\right),
\end{aligned}
$$

where:

$$
\mathrm{L}_{\mathrm{i}}=\mathrm{L}_{\mathrm{Lk}_{-} \mathrm{i}}+\mathrm{L}_{\mathrm{m}_{-} \mathrm{i}} \text {. }
$$

In the same way, the current through the capacitor of the trap is:

$$
\begin{aligned}
\mathrm{i}_{\mathrm{Ci}}\left(\mathrm{t}^{\prime}\right) & =\mathrm{j} \cdot 2 \cdot \pi \cdot \mathrm{f}_{\mathrm{i}} \cdot \mathrm{C}_{\mathrm{i}} \cdot \mathrm{v}_{\text {Trap_i_hl }}\left(\mathrm{t}^{\prime}\right)= \\
& =2 \cdot \pi \cdot \mathrm{f}_{\mathrm{i}} \cdot \mathrm{C}_{\mathrm{i}} \cdot \mathrm{A}_{\mathrm{h} 1}\left(\mathrm{D}, \mathrm{V}_{\mathrm{in}}\right) \cdot \sin \left(2 \cdot \pi \cdot \mathrm{f}_{\mathrm{i}} \cdot \mathrm{t}^{\prime}+\frac{\pi}{2}\right) .
\end{aligned}
$$

Both currents have been represented in Fig. 5 a.

The diode will be directly biased when the voltage in the secondary side of the transformer is equal to the voltage of the cell plus the knee voltage of the diode (Fig. 4a):

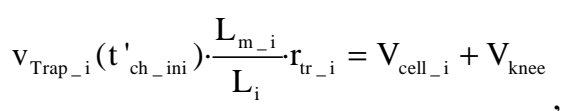

where $V_{\text {knee }}$ is the knee voltage of the rectifier diode, $r_{t r \_i}$ is the turns ratio of trap $i$ transformer $\left(r_{t_{-}-i}=n_{2} / n_{1}\right)$, and $t_{\text {'ch_ini }}$ (see Fig. 5b) is the instant when the charging process of the cell starts. With (8), (12) and (17) it is possible to obtain $\mathrm{t}_{\text {'ch_ini: }}$

$$
\begin{aligned}
\mathrm{t}_{\mathrm{ch}_{-} \text {ini }}^{\prime}= & \frac{1}{2 \cdot \pi \cdot \mathrm{f}_{\mathrm{i}}} \\
& \cdot \operatorname{asin}\left(\frac{\mathrm{V}_{\text {cell_i } \mathrm{i}}+\mathrm{V}_{\text {knee }}}{\mathrm{r}_{\mathrm{tr}_{-} \mathrm{i}}} \cdot \frac{\mathrm{L}_{\mathrm{i}}}{\mathrm{L}_{\mathrm{m}_{-} \mathrm{i}}} \cdot \frac{\pi}{2 \cdot \mathrm{V}_{\text {in }} \cdot \sin (\pi \cdot \mathrm{D})}\right) .
\end{aligned}
$$

When the diode is directly biased, the valid circuit is Fig. 4c. Therefore, the current injected into the chosen cell is:

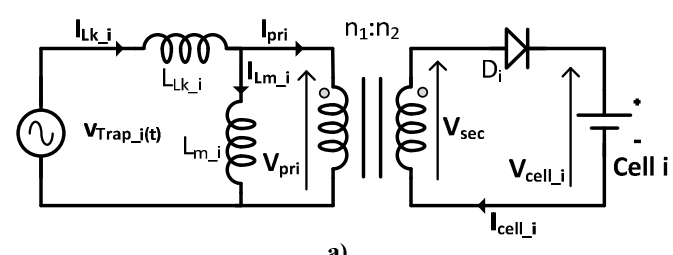

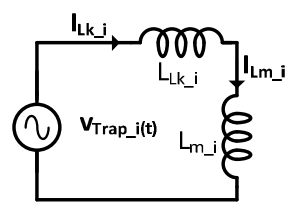

b)

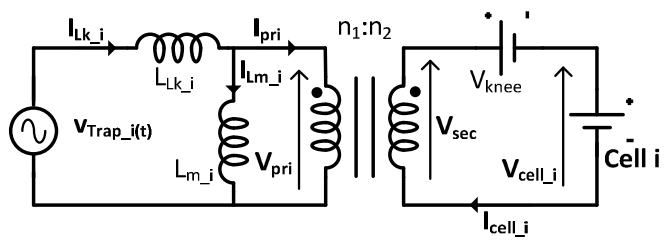

Fig. 4. a) Equivalent circuit of the trap; b) Equivalent circuit when the diode is reverse biased; c) Equivalent circuit when the diode is directly biased. 


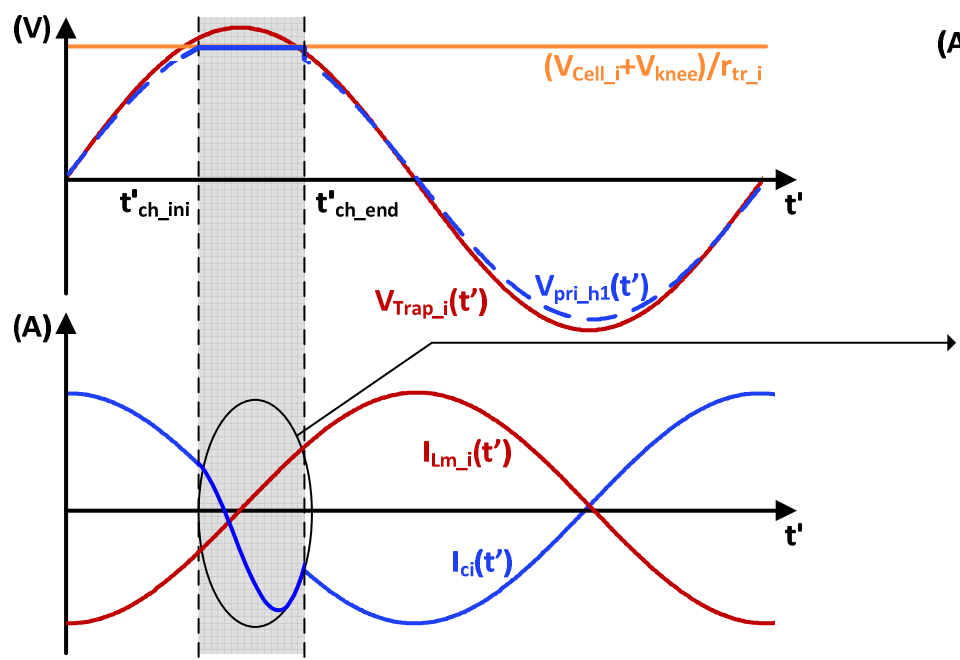

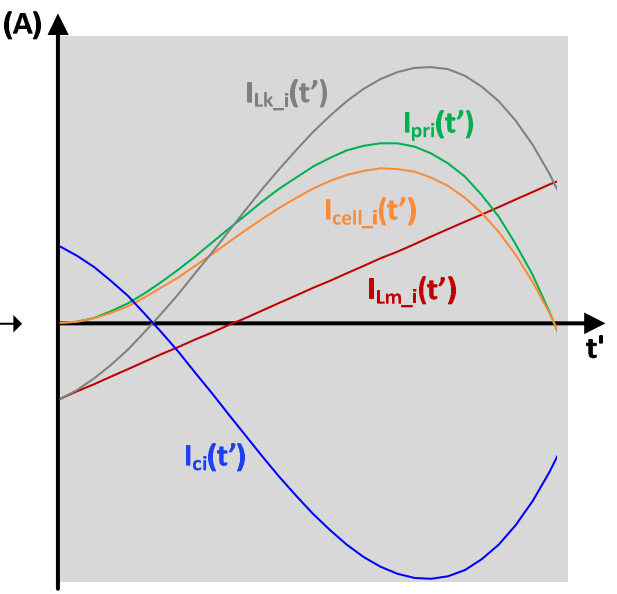

b)

Fig. 5. a) Main voltages and currents; b) detail of the currents between $t^{\prime}$ ch_ini and $t^{\prime}$ ch_end.

$$
\mathrm{i}_{\text {cell } \_\mathrm{i}}\left(\mathrm{t}^{\prime}\right)=\frac{1}{\mathrm{r}_{\mathrm{tr}_{-} \mathrm{i}}}\left(\mathrm{i}_{\mathrm{Lk}_{-} \mathrm{i}}\left(\mathrm{t}^{\prime}\right)-\mathrm{i}_{\mathrm{Lm}_{-} \mathrm{i}}\left(\mathrm{t}^{\prime}\right)\right)
$$

where:

$$
\begin{aligned}
& \mathrm{i}_{\mathrm{Lm}_{-} \mathrm{i}}\left(\mathrm{t}^{\prime}\right)=\mathrm{i}_{\mathrm{Lm}_{-} \mathrm{i}}\left(\mathrm{t}^{\prime}{ }_{\mathrm{ch} \_ \text {ini }}\right)+ \\
& +\frac{1}{\mathrm{~L}_{\mathrm{m}_{-} \mathrm{i}}} \cdot \int_{\mathrm{t}^{\prime} \mathrm{ch}_{-} \mathrm{ini}^{\prime}}^{\mathrm{t}^{\prime}} \frac{1}{\mathrm{r}_{\mathrm{tr}_{-} \mathrm{i}}} \cdot\left(\mathrm{v}_{\mathrm{cell}_{-} \mathrm{i}}+\mathrm{V}_{\mathrm{knee}}\right) \cdot \mathrm{dt}^{\prime}, \\
& \mathrm{i}_{\mathrm{Lk}_{-} \mathrm{i}}\left(\mathrm{t}^{\prime}\right)=\mathrm{i}_{\mathrm{Lk}_{-} \mathrm{i}}\left(\mathrm{t}^{\prime}{ }_{\mathrm{Ch} \_ \text {ini }}\right)+
\end{aligned}
$$

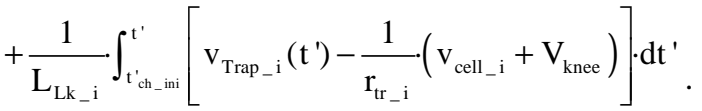

Taking into account that $\mathrm{i}_{\mathrm{Lm}_{-} \mathrm{i}}\left(\mathrm{t}^{\prime}{ }_{\text {ch_ini }}\right)=\mathrm{i}_{\text {Lk_i }_{i}}\left(\mathrm{t}^{\prime}{ }_{\text {ch_ini }}\right)$, (19) becomes:

$$
\begin{aligned}
& \mathrm{i}_{\text {cell_i }}\left(\mathrm{t}^{\prime}\right)=
\end{aligned}
$$

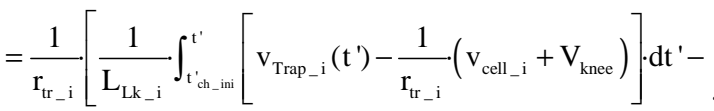

$$
\begin{aligned}
& \left.-\frac{1}{\mathrm{~L}_{\mathrm{m}_{-} \mathrm{i}}} \int_{\mathrm{t}^{\prime} \mathrm{c}_{-} \text {_nin }}^{\mathrm{t}^{\prime}} \frac{1}{\mathrm{r}_{\mathrm{tr} \_} \mathrm{i}} \cdot\left(\mathrm{v}_{\text {cell }_{-} \mathrm{i}}+\mathrm{V}_{\text {knee }}\right) \cdot \mathrm{dt}^{\prime}\right] \\
& \mathrm{i}_{\text {cell_i }}\left(\mathrm{t}^{\prime}\right)= \\
& =\frac{A_{h 1}\left(D, V_{\text {in }}\right) \cdot\left(\cos \left(2 \cdot \pi \cdot f_{i} \cdot t^{\prime}{ }_{\text {ch_ini }}\right)-\cos \left(2 \cdot \pi \cdot f_{i} \cdot t^{\prime}\right)\right)}{r_{\mathrm{tr}_{-} \mathrm{i}} \cdot L_{\mathrm{Lk}_{-} \mathrm{i}} \cdot 2 \cdot \pi \cdot \mathrm{f}_{\mathrm{i}}}+ \\
& +\frac{\left(\mathrm{V}_{\text {cell_i }}+\mathrm{V}_{\mathrm{knee}}\right) \cdot\left(\mathrm{t}_{{ }_{\mathrm{ch} \_}{ }_{\mathrm{ini}}}-\mathrm{t}^{\prime}\right)}{\mathrm{r}_{\mathrm{tr} \_\mathrm{i}}^{2}} \cdot\left(\frac{1}{\mathrm{~L}_{\mathrm{Lk}_{-} \mathrm{i}}}+\frac{1}{\mathrm{~L}_{\mathrm{m}_{-} \mathrm{i}}}\right)
\end{aligned}
$$

The diode will be directly biased until the current injected into the cell becomes zero, at $\mathrm{t}_{\text {'ch_end }}$ :

$$
\mathrm{i}_{\text {cell_ } \mathrm{i}}\left(\mathrm{t}_{{ }_{\text {ch_end }}}\right)=0
$$

Finally, the average current injected into the chosen battery cell can be calculated very easily:

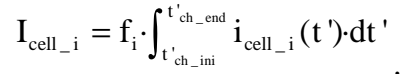

where $I_{\text {cell_i }}$ denotes the average value of the current injected into the battery cell.
The current injected into the cell should be controlled in order not to exceed certain levels which would mean damaging that battery cell or the whole pack and, also, in order to be able to precisely control the final voltage of the cell. As can be seen in (23), the current injected into the cell depends on the amplitude of the first harmonic component of the voltage withstood by the trap $\left(\mathrm{A}_{\mathrm{h} 1}\left(\mathrm{D}, \mathrm{V}_{\mathrm{in}}\right)\right)$ and, therefore, on the duty cycle $\mathrm{D}$. As a consequence, the proposed equalizer can control the amount of energy injected into the cell during each switching period. Therefore, the system has two control variables. The first one is the switching frequency, which defines the trap that is going to be excited and, consequently, which cell is going to be charged. The second one is the duty cycle, which precisely defines the current injected into the chosen cell.

The maximum value of the current $i_{\text {cell }_{i}}\left(t^{\prime}\right)$, given in equation (23), corresponds to the maximum value of $\mathrm{A}_{\mathrm{h} 1}\left(\mathrm{D}, \mathrm{V}_{\text {in }}\right)$, which takes place when $\mathrm{D}=0.5$ as can be seen in (8). Therefore,

$$
\begin{aligned}
& \mathrm{i}_{\text {cell_i_max }}\left(\mathrm{t}^{\prime}\right)= \\
& =\frac{\mathrm{V}_{\mathrm{in}} \cdot\left(\cos \left(2 \cdot \pi \cdot \mathrm{f}_{\mathrm{i}} \cdot \mathrm{t}^{\prime}{ }_{\mathrm{ch} \_ \text {ini }}\right)-\cos \left(2 \cdot \pi \cdot \mathrm{f}_{\mathrm{i}} \cdot \mathrm{t}^{\prime}\right)\right)}{\mathrm{r}_{\mathrm{tr}_{-} \mathrm{i}} \cdot \mathrm{L}_{\mathrm{Lk}_{-} \mathrm{i}} \cdot \pi^{2} \cdot \mathrm{f}_{\mathrm{i}}}+ \\
& +\frac{\left(\mathrm{V}_{\text {cell_ } \mathrm{i}}+\mathrm{V}_{\mathrm{knee}}\right) \cdot\left(\mathrm{t}_{\mathrm{ch}_{-} \text {ini }}-\mathrm{t}^{\prime}\right)}{\mathrm{r}_{\mathrm{tr}_{-} \mathrm{i}}^{2}} \cdot\left(\frac{1}{\mathrm{~L}_{\mathrm{Lk}_{-} \mathrm{i}}}+\frac{1}{\mathrm{~L}_{\mathrm{m}_{-} \mathrm{i}}}\right)
\end{aligned}
$$

Considering this equation and (25), the maximum average current injected into the cell can be defined as:

$$
I_{\text {cell__i_max }}=f_{i} \cdot \int_{t_{\text {ch__ni }}}^{t_{\text {ch_end }}^{\prime}} i_{\text {cell_i } i_{-} \text {max }}\left(t^{\prime}\right) \cdot d t^{\prime}
$$

Defining $\mathrm{L}_{\mathrm{p} \_\mathrm{i}}$ as the parallel connection of $\mathrm{L}_{\mathrm{Lk} \_\mathrm{i}}$ and $\mathrm{L}_{\mathrm{m} \_\mathrm{i}}$, and $\lambda_{\mathrm{i}}$ as:

$$
\lambda_{\mathrm{i}}=\frac{\mathrm{L}_{\mathrm{Lk}_{-} \mathrm{i}}}{\mathrm{L}_{\mathrm{p}_{-} \mathrm{i}}}=\frac{\mathrm{L}_{\mathrm{m}_{-} \mathrm{i}}+\mathrm{L}_{\mathrm{Lk}_{-} \mathrm{i}}}{\mathrm{L}_{\mathrm{m}_{-} \mathrm{i}}}
$$

equation (26) becomes: 


$$
\begin{aligned}
& \mathrm{i}_{\text {cell_i_max }}\left(\mathrm{t}^{\prime}\right)= \\
& =\frac{1}{\mathrm{r}_{\mathrm{tr}_{-} \mathrm{i}}^{2} \cdot 2 \cdot \pi \cdot \mathrm{f}_{\mathrm{i}} \cdot \mathrm{L}_{\mathrm{Lk}_{-} \mathrm{i}}} \text {. } \\
& {\left[\frac{2 \cdot r_{\text {tr }_{-}} \cdot \mathrm{V}_{\text {in }} \cdot\left(\cos \left(2 \cdot \pi \cdot \mathrm{f}_{\mathrm{i}} \cdot \mathrm{t}_{\mathrm{ch}_{-} \mathrm{ini}_{\mathrm{in}}}\right)-\cos \left(2 \cdot \pi \cdot \mathrm{f}_{\mathrm{i}} \cdot \mathrm{t}^{\prime}\right)\right)}{\pi}+.\right.} \\
& \left.+2 \cdot \pi \cdot f_{i} \cdot \lambda_{i} \cdot\left(V_{\text {cell_ } i}+V_{\text {knee }}\right) \cdot\left(t^{\prime}{ }_{\text {ch_ini }}^{\prime}-t^{\prime}\right)\right]
\end{aligned}
$$

Also, defining the parameters $\mu_{\mathrm{i}}, \varphi_{\mathrm{i}}, \varphi_{\text {ini }}$ and $\varphi_{\text {end }}$ as:

$$
\begin{gathered}
\mu_{\mathrm{i}}=\frac{\mathrm{V}_{\text {cell_i }}+\mathrm{V}_{\text {knee }}}{\mathrm{V}_{\mathrm{in}}}, \\
\varphi_{\mathrm{i}}=2 \cdot \pi \cdot \mathrm{f}_{\mathrm{i}} \cdot \mathrm{t}^{\prime}, \\
\varphi_{\text {ini }}=2 \cdot \pi \cdot \mathrm{f}_{\mathrm{i}} \cdot \mathrm{t}^{\prime}{ }_{\text {ch_ini }}, \\
\varphi_{\text {end }}=2 \cdot \pi \cdot \mathrm{f}_{\mathrm{i}} \cdot \mathrm{t}^{\prime}{ }_{\text {ch_end }},
\end{gathered}
$$

equation (29) becomes:

$$
\begin{aligned}
& \mathrm{i}_{\text {cell_ } \mathrm{i}_{-} \text {max }}\left(\mathrm{t}^{\prime}\right)= \\
& =\frac{\mathrm{V}_{\mathrm{in}}}{\mathrm{r}_{\mathrm{tr}_{-} \mathrm{i}}^{2} \cdot 2 \cdot \pi \cdot \mathrm{f}_{\mathrm{i}} \cdot \mathrm{L}_{\mathrm{Lk}_{-} \mathrm{i}}} \\
& \cdot\left[\frac{2 \cdot \mathrm{r}_{\mathrm{tr}_{-} \mathrm{i}} \cdot\left(\cos \varphi_{\mathrm{ini}}-\cos \varphi_{\mathrm{i}}\right)}{\pi}+\lambda_{\mathrm{i}} \cdot \mu_{\mathrm{i}} \cdot\left(\varphi_{\mathrm{ini}}-\varphi_{\mathrm{i}}\right)\right]
\end{aligned}
$$

This equation can be normalized by dividing $i_{\text {cell_i_max }}\left(t^{\prime}\right)$ by the base current $I_{\text {base_i }}$ :

$$
I_{\text {base }_{-} i}=\frac{V_{\text {in }}}{2 \cdot \pi \cdot f_{i} \cdot L_{L_{-} i}} \text {, }
$$

obtaining:

$$
\begin{aligned}
& \gamma_{\mathrm{i}}=\frac{\mathrm{i}_{\text {cell_ } \mathrm{i}_{-} \max }\left(\mathrm{t}^{\prime}\right)}{\mathrm{I}_{\text {base }_{-} \mathrm{i}}}= \\
& =\frac{1}{\mathrm{r}_{\mathrm{tr} \_\mathrm{i}}^{2}} \cdot\left[\frac{2 \cdot \mathrm{r}_{\mathrm{tr}_{-} \mathrm{i}} \cdot\left(\cos \varphi_{\mathrm{ini}}-\cos \varphi_{\mathrm{i}}\right)}{\pi}+\lambda_{\mathrm{i}} \cdot \mu_{\mathrm{i}} \cdot\left(\varphi_{\mathrm{ini}}-\varphi_{\mathrm{i}}\right)\right] .
\end{aligned}
$$

From (18), (32) becomes:

$$
\varphi_{\text {ini }}=\operatorname{asin}\left(\frac{\mu_{i} \cdot \lambda_{i}}{r_{t_{r} i}} \cdot \frac{\pi}{2}\right),
$$

Similarly, $\varphi_{\text {end }}$ can be obtained by making $\gamma_{i}$ equal to zero and solving:

$$
\cos \varphi_{\text {ini }}-\cos \varphi_{\text {end }}=\frac{\mu_{\mathrm{i}} \cdot \lambda_{\mathrm{i}}}{\mathrm{r}_{\mathrm{tr} \_\mathrm{i}}} \cdot \frac{\pi}{2} \cdot\left(\varphi_{\text {end }}-\varphi_{\mathrm{ini}}\right)
$$

Once $\varphi_{\text {end }}$ is obtained, the conduction angle $\Delta \varphi_{c}$ can be easily obtained:

$$
\Delta \varphi_{\mathrm{c}}=\varphi_{\text {end }}-\varphi_{\text {ini }} .
$$

The normalized maximum average current injected into the cell is (from (27)):

$$
\Gamma_{\mathrm{i}}=\frac{\mathrm{I}_{\text {cell__i_max }}}{\mathrm{I}_{\text {base_i }}}=\frac{1}{2 \cdot \pi} \int_{\varphi_{\text {ini }}}^{\varphi_{\text {end }}} \gamma_{\mathrm{i}}\left(\varphi_{\mathrm{i}}\right) \cdot \mathrm{d} \varphi_{\mathrm{i}}
$$

It should be taken into account that the magnetizing inductance of the transformer is considerably higher than its leakage inductance. Therefore, (28) becomes:

$$
\lambda_{\mathrm{i}} \approx 1 \text {, }
$$

and hence, (18), (36), (37) and (38) become:

$$
\begin{gathered}
\mathrm{t}_{\mathrm{ch}_{-} \mathrm{ini}}^{\prime} \approx \frac{1}{2 \cdot \pi \cdot \mathrm{f}_{\mathrm{i}}} \cdot \mathrm{a} \sin \left(\frac{\mathrm{V}_{\mathrm{cell}_{-} \mathrm{i}}+\mathrm{V}_{\mathrm{knee}}}{\mathrm{r}_{\mathrm{tr}_{-} \mathrm{i}}} \cdot \frac{\pi}{2 \cdot \mathrm{V}_{\mathrm{in}} \cdot \sin (\pi \cdot \mathrm{D})}\right) . \\
\gamma_{\mathrm{i}} \approx \frac{1}{\mathrm{r}_{\mathrm{tr} \_\mathrm{i}}^{2}} \cdot\left[\frac{2 \cdot \mathrm{r}_{\mathrm{tr}_{-} \mathrm{i}} \cdot\left(\cos \varphi_{\mathrm{ini}}-\cos \varphi_{\mathrm{i}}\right)}{\pi}+\mu_{\mathrm{i}} \cdot\left(\varphi_{\mathrm{ini}}-\varphi_{\mathrm{i}}\right)\right] . \\
\varphi_{\mathrm{ini}} \approx \mathrm{a} \sin \left(\frac{\mu_{\mathrm{i}}}{\mathrm{r}_{\mathrm{tr}_{-} \mathrm{i}}} \cdot \frac{\pi}{2}\right) . \\
\cos \varphi_{\mathrm{ini}}-\cos \varphi_{\mathrm{end}} \approx \frac{\mu_{\mathrm{i}_{1}}}{\mathrm{r}_{\mathrm{tr} \_\mathrm{i}}} \cdot \frac{\pi}{2}\left(\varphi_{\text {end }}-\varphi_{\mathrm{ini}}\right)
\end{gathered}
$$

For the sake of simplicity, it can be considered that the voltage of all the cells is nearly the same (i.e., $\mathrm{V}_{\text {cell_ }} \approx \mathrm{V}_{\text {cell }}$ ) because the voltage imbalance is usually small in comparison to the voltage of the cells. Also, the input voltage of the half-bridge structure is the voltage of the cell pack. Therefore, $\mathrm{V}_{\text {in }} \approx \mathrm{V}_{\text {cell }} \cdot \mathrm{n}_{\text {cell }}, \mathrm{n}_{\text {cell }}$ being the number of cells connected in series. As a consequence, equation (30) becomes:

$$
\mu_{\mathrm{i}}=\frac{1+\mathrm{v}_{\mathrm{knee}}}{\mathrm{n}_{\text {cell }}}
$$

where $v_{\text {knee }}$ is:

$$
\mathrm{V}_{\text {knee }}=\frac{\mathrm{V}_{\mathrm{knee}}}{\mathrm{V}_{\text {cell }}} \text {. }
$$

The evolution of the conduction angle $\Delta \varphi_{\mathrm{c}}$ as a function of the turns ratio $r_{t_{-} i}$ for different number of cells $\left(\mathrm{n}_{\text {cell }}\right)$ and for different values of $v_{\text {knee }}$ can be computed from (39), (44), the solution of (45), and (46). Fig. 6 shows the results obtained for values of $n_{\text {cell }}$ around 4 , which will be used in the section IV.B and section V.

In the same way, $\Gamma_{i}$ can be also expressed as a function of $r_{t r \_i}, n_{\text {cell }}$, and $v_{\text {knee }}$. The results are given in Fig. 7.

\section{DESIGN GUIDELINE}

In the design of the proposed trap-based equalizer it is mandatory to take into account several issues.

\section{A. Influence of tolerances}

For a given trap, the nominal resonant frequency is defined by (2). For this analysis, it has been assumed that the resonant frequency of trap $i$ is lower than the resonant frequency of trap $i+1$ :

$$
\mathrm{f}_{\mathrm{i}}<\mathrm{f}_{\mathrm{i}+1} \text {. }
$$

The actual resonant frequency of any trap will be inside a range defined by the tolerances of its inductor and its capacitor. Its resonant frequency may be as low as:

$$
\begin{aligned}
\mathrm{f}_{\text {min_i }_{-}} & =\frac{1}{2 \cdot \pi \cdot \sqrt{\mathrm{L}_{\mathrm{i}} \cdot\left(1+\operatorname{tol}_{\mathrm{L}}\right) \cdot \mathrm{C}_{\mathrm{i}} \cdot\left(1+\operatorname{tol}_{\mathrm{C}}\right)}}= \\
& =\frac{\mathrm{f}_{\mathrm{i}}}{\sqrt{\left(1+\mathrm{tol}_{\mathrm{L}}\right) \cdot\left(1+\operatorname{tol}_{\mathrm{C}}\right)}}
\end{aligned}
$$



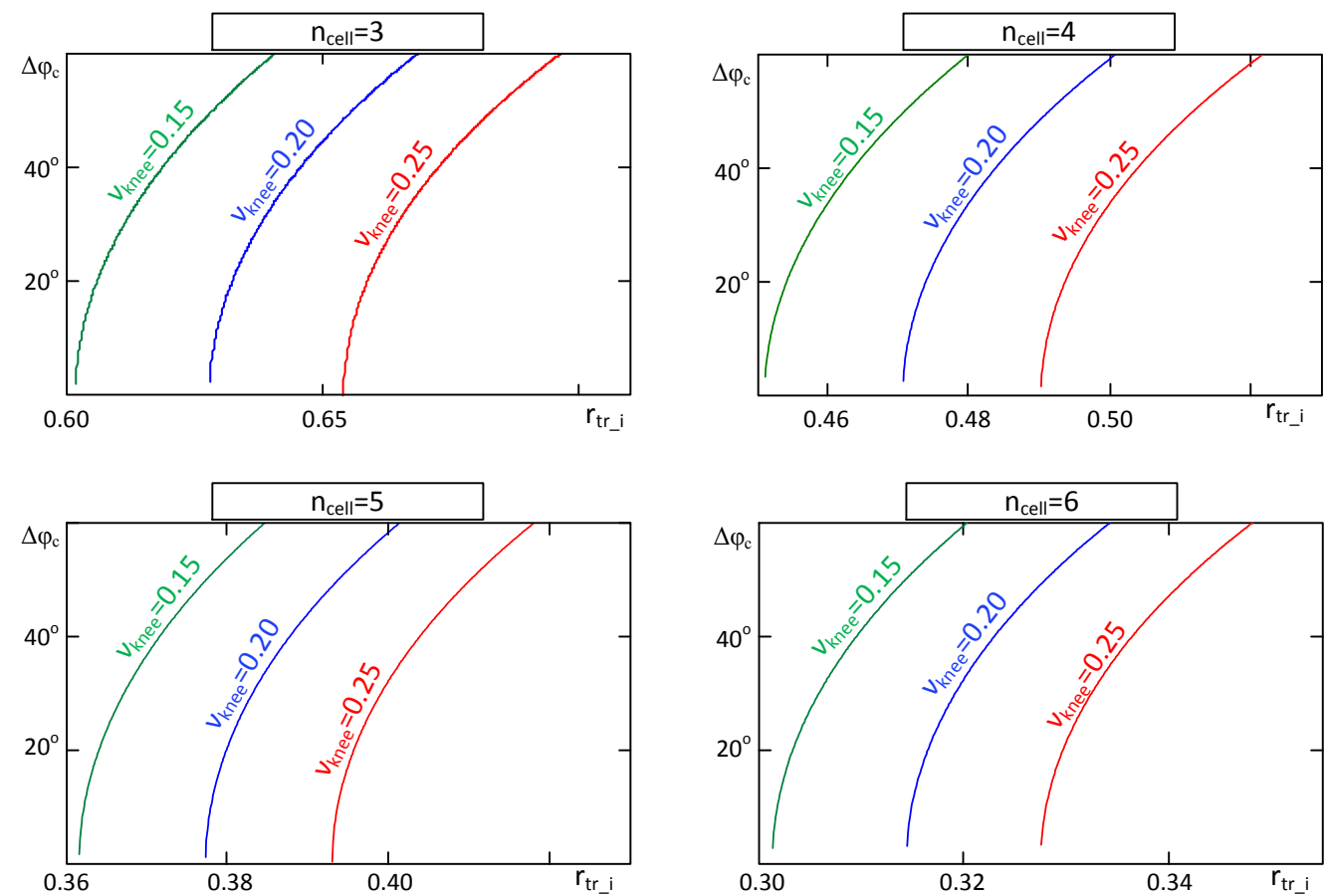

Fig. 6. Conduction angle as a function of $\mathrm{r}_{\mathrm{tr} i \mathrm{i}}$ for values of $\mathrm{n}_{\text {cell }}$ around four, which is the number of cells used in the experimental results.
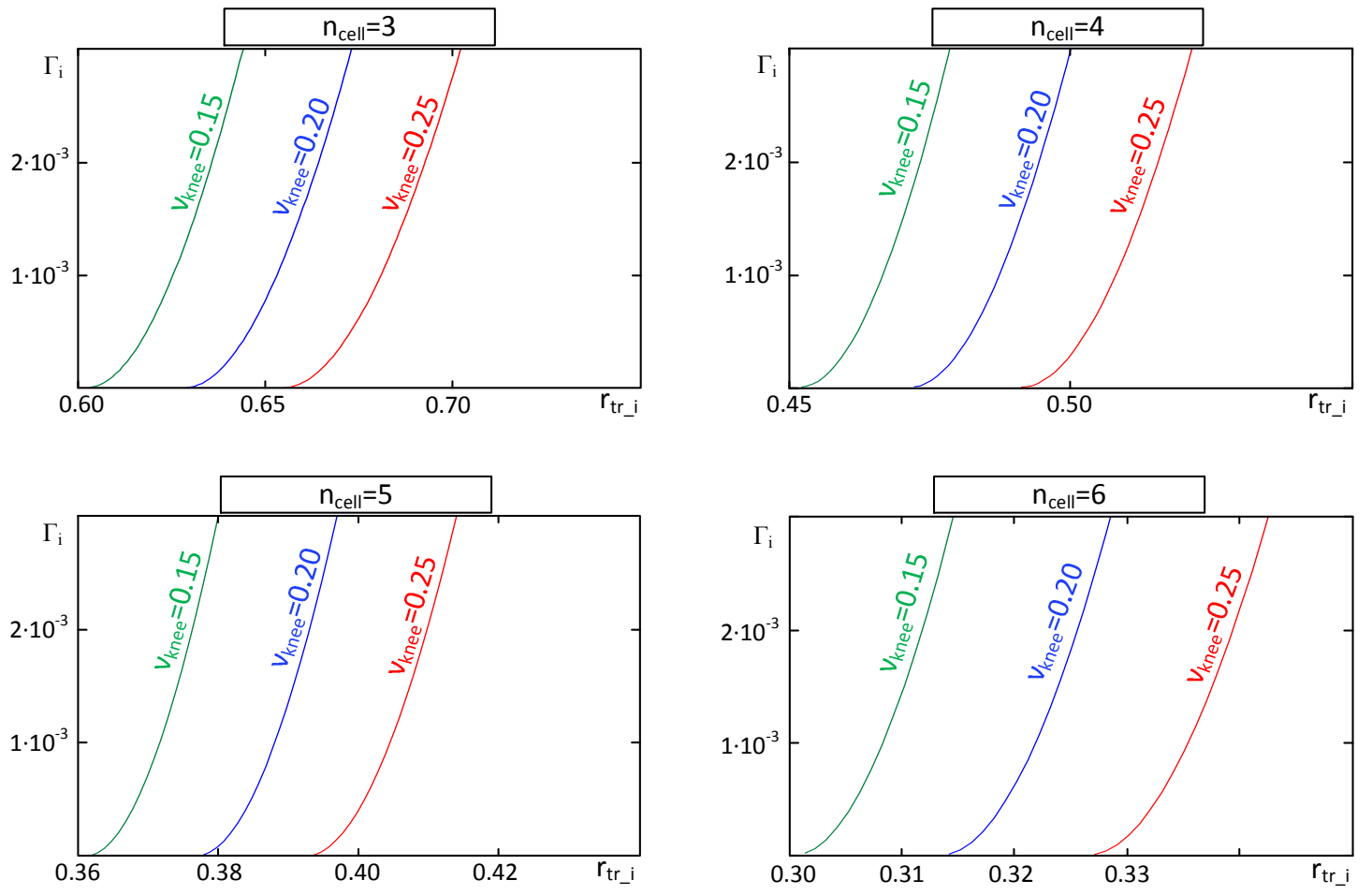

Fig. 7. Normalized maximum average current as a function of the turns ratio for values of $n_{\text {cell }}$ around four.

where tol $\mathrm{L}_{\mathrm{L}}$ and tol $_{\mathrm{C}}$ are the tolerances of the inductor and the capacitor of the trap. Its maximum resonant frequency due to tolerances is:

$$
\begin{aligned}
\mathrm{f}_{\text {max }_{-} \mathrm{i}} & =\frac{1}{2 \cdot \pi \cdot \sqrt{\mathrm{L}_{\mathrm{i}} \cdot\left(1-\mathrm{tol}_{\mathrm{L}}\right) \cdot \mathrm{C}_{\mathrm{i}} \cdot\left(1-\mathrm{tol}_{\mathrm{C}}\right)}}= \\
& =\frac{\mathrm{f}_{\mathrm{i}}}{\sqrt{\left(1-\mathrm{tol}_{\mathrm{L}}\right) \cdot\left(1-\operatorname{tol}_{\mathrm{C}}\right)}} .
\end{aligned}
$$

The proposed equalizer would work properly even when the resonant frequencies of the traps were not exactly equal to the theoretical ones as long as their relative positions were not affected. In other words, any trap may change its resonant frequency as long as it does not become lower or higher than the resonant frequency of an adjacent trap. If this condition is introduced in the design process, then the resulting system is robust and is not negatively affected by tolerances. The mathematical expression of this condition is: 


$$
\begin{aligned}
& \mathrm{f}_{\text {max } \_i_{i}}<\mathrm{f}_{\text {min_i } \_+1} \Rightarrow \\
& \Rightarrow \frac{\mathrm{f}_{\mathrm{i}}}{\sqrt{\left(1-\text { tol }_{\mathrm{L}}\right) \cdot\left(1-\mathrm{tol}_{\mathrm{C}}\right)}}<\frac{\mathrm{f}_{\mathrm{i}+1}}{\sqrt{\left(1+\operatorname{tol}_{\mathrm{L}}\right) \cdot\left(1+\operatorname{tol}_{\mathrm{C}}\right)}} .
\end{aligned}
$$

Therefore:

$$
\mathrm{f}_{\mathrm{i}+1}>\sqrt{\frac{\left(1+\operatorname{tol}_{\mathrm{L}}\right) \cdot\left(1+\mathrm{tol}_{\mathrm{C}}\right)}{\left(1-\text { tol }_{\mathrm{L}}\right) \cdot\left(1-\text { tol }_{\mathrm{C}}\right)}} \cdot \mathrm{f}_{\mathrm{i}}=\tau_{\text {tol }} \cdot \mathrm{f}_{\mathrm{i}}
$$

where $\tau_{\text {tol }}$ is defined by the tolerances of the trap components. value of $\mathrm{f}_{1}$ :

The design should start by choosing the minimum

$$
\mathrm{f}_{\text {min }_{-1}}=\frac{1}{2 \cdot \pi \cdot \sqrt{\mathrm{L}_{1} \cdot \mathrm{C}_{1}}} \cdot \frac{1}{\sqrt{\left(1+\operatorname{tol}_{\mathrm{L}}\right) \cdot\left(1+\operatorname{tol}_{\mathrm{C}}\right)}}
$$

so,

$$
\mathrm{L}_{1} \cdot \mathrm{C}_{1}=\frac{1}{\left(2 \cdot \pi \cdot \mathrm{f}_{\text {min_1 }}\right)^{2}} \cdot \frac{1}{\left(1+\operatorname{tol}_{\mathrm{L}}\right) \cdot\left(1+\operatorname{tol}_{\mathrm{C}}\right)}
$$

Once the product $\mathrm{L}_{1} \cdot \mathrm{C}_{1}$ of the first trap is obtained, it is possible to follow an iterative process in which (52) is used to calculate the $\mathrm{L} \cdot \mathrm{C}$ product of the next trap based on the $\mathrm{L} \cdot \mathrm{C}$ product of the previous one.

\section{B. Calculation of the inductance, the capacitance} and the turns ratio of each trap

There are infinite solutions for designing each trap as only the corresponding $\mathrm{L}_{\mathrm{i}} \cdot \mathrm{C}_{\mathrm{i}}$ value has been obtained in section IV.A. Nevertheless, it is possible to optimize the design of the proposed equalizer considering additional conditions which will lead to specific values of the capacitance and the inductance of each trap. defined as:

The specific impedance $Z_{i}$ of each trap can be

$$
\mathrm{Z}_{\mathrm{i}}=\sqrt{\frac{\mathrm{L}_{\mathrm{i}}}{\mathrm{C}_{\mathrm{i}}}} .
$$

The resonant current driven by the inductor of the chosen trap was defined in (14). Considering this equation, (2) and (55):

$$
\mathrm{i}_{\mathrm{Lm}_{-} \mathrm{i}}\left(\mathrm{t}^{\prime}\right)=\mathrm{i}_{\mathrm{Lk}_{-} \mathrm{i}}\left(\mathrm{t}^{\prime}\right)=\frac{\mathrm{A}_{\mathrm{h} 1}\left(\mathrm{D}, \mathrm{V}_{\mathrm{in}}\right)}{\mathrm{Z}_{\mathrm{i}}} \cdot \sin \left(2 \cdot \pi \cdot \mathrm{f}_{\mathrm{i}} \cdot \mathrm{t}^{\prime}-\frac{\pi}{2}\right) \text {. }
$$

In the same way, the current driven by the capacitor (defined in (16)) is:

$$
\mathrm{i}_{\mathrm{Ci}}\left(\mathrm{t}^{\prime}\right)=\frac{\mathrm{A}_{\mathrm{h} 1}\left(\mathrm{D}, \mathrm{V}_{\mathrm{in}}\right)}{\mathrm{Z}_{\mathrm{i}}} \cdot \sin \left(2 \cdot \pi \cdot \mathrm{f}_{\mathrm{i}} \cdot \mathrm{t}^{\prime}+\frac{\pi}{2}\right)
$$

Considering $\mathrm{D}=0.5,(56)$ and (57) becomes:

$$
\begin{gathered}
\mathrm{i}_{\mathrm{Lm}_{-} \mathrm{i}_{-} \max }\left(\mathrm{t}^{\prime}\right)=\mathrm{i}_{\mathrm{Lk}_{-} \mathrm{i}_{-} \max }\left(\mathrm{t}^{\prime}\right)=\frac{2 \cdot \mathrm{V}_{\mathrm{in}}}{\mathrm{Z}_{\mathrm{i}} \cdot \pi} \cdot \sin \left(2 \cdot \pi \cdot \mathrm{f}_{\mathrm{i}} \cdot \mathrm{t}^{\prime}-\frac{\pi}{2}\right), \\
\mathrm{i}_{\mathrm{Ci}_{-} \max }\left(\mathrm{t}^{\prime}\right)=\frac{2 \cdot \mathrm{V}_{\text {in }}}{\mathrm{Z}_{\mathrm{i}} \cdot \pi} \cdot \sin \left(2 \cdot \pi \cdot \mathrm{f}_{\mathrm{i}} \cdot \mathrm{t}^{\prime}+\frac{\pi}{2}\right) .
\end{gathered}
$$

The ratio between the energy in the resonant circuit (i.e., chosen trap) and the energy injected into the chosen cell during each switching period is denoted by $\mathrm{Q}_{\mathrm{E}_{-} \mathrm{i}}$ and can be defined as:

$$
\mathrm{Q}_{\mathrm{E}_{-} \mathrm{i}}=\frac{\mathrm{E}_{\mathrm{res}_{-} \mathrm{i}}}{\mathrm{E}_{\text {cell } \_\mathrm{i}},}
$$

where $E_{\text {res_i }}$ is the energy in the resonant circuit and $E_{\text {cell_i }}$ the energy injected into the cell. If the amount of energy injected into the cell is lower than the amount of resonant energy that the chosen trap is handling, then the behavior of the string of traps will not depend on whether the diode is reverse biased or not. This means that the voltage across the capacitor of the trap will be sinusoidal even during the short periods of time when the diode is conducting. Hence, it is interesting to design the system with values of $\mathrm{Q}_{\mathrm{E}_{\mathrm{i}} \mathrm{i}}$ higher than unity so that the behavior of the trap is not affected by the cell (see later in this section).

The resonant energy in the chosen trap can be obtained from its voltage and the value of its capacitor (when the voltage in the trap is the peak one, the energy in the inductor is zero):

$$
\mathrm{E}_{\text {res_i }}=\mathrm{C}_{\mathrm{i}} \cdot \frac{2 \cdot \mathrm{V}_{\mathrm{in}}^{2}}{\pi^{2}}
$$

The energy injected into the cell in each switching period can be denoted as:

$$
\mathrm{E}_{\text {cell_i }}=\frac{\mathrm{I}_{\text {cell_i_max }} \cdot \mathrm{V}_{\text {cell_i }}}{\mathrm{f}_{\mathrm{i}}} \text {. }
$$

Hence,

$$
\mathrm{Q}_{\mathrm{E}_{-} \mathrm{i}}=\frac{2 \cdot \mathrm{f}_{\mathrm{i}} \cdot \mathrm{C}_{\mathrm{i}} \cdot \mathrm{V}_{\mathrm{in}}^{2}}{\pi^{2} \cdot \mathrm{V}_{\text {cell__i }} \cdot \mathrm{I}_{\text {cell_i_max }}}
$$
becomes:

Taking into account (2) and (55), then (63)

$$
\mathrm{Q}_{\mathrm{E}_{-} \mathrm{i}}=\frac{\mathrm{V}_{\mathrm{in}}^{2}}{\pi^{3} \cdot \mathrm{Z}_{\mathrm{i}} \cdot \mathrm{V}_{\text {cell_ } \mathrm{i}} \cdot \mathrm{I}_{\text {cell_ } \mathrm{i}_{-} \max }} .
$$

Fig. 8 shows the waveforms corresponding to the voltage across the resonant capacitors and the current injected into the cells obtained for different values of $\mathrm{Q}_{\mathrm{E}_{\mathrm{i}} \text {. }}$. As Fig. 8 shows, the voltage across the capacitor can be
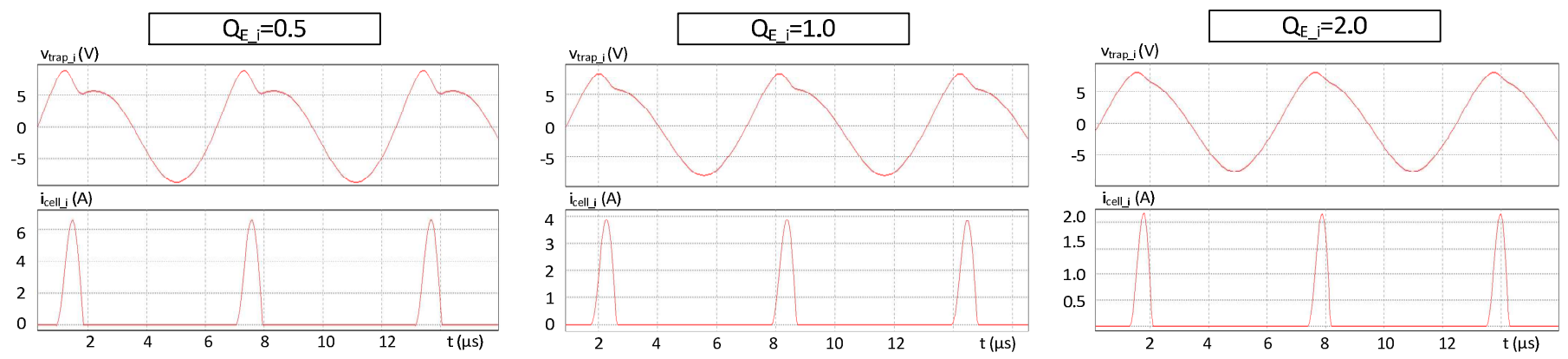

Fig. 8. Trap voltage and cell current for different values of $\mathrm{Q}_{\mathrm{E}}$. The distortion in the trap voltage depends on this parameter. 
considered sinusoidal when the value of $\mathrm{Q}_{\mathrm{E}_{\mathrm{i}}}$ is higher than two. However, very high values of $\mathrm{Q}_{\mathrm{E}_{-} \mathrm{i}}$ lead to high circulating currents through the resonant capacitor and inductor, as can be deduced from (58), (59) and (64). As a consequence, a tradeoff must be met when choosing the values of $\mathrm{Q}_{\mathrm{E}_{\mathrm{i}} \mathrm{i}}$ in order to obtain a system in which efficiency is not excessively affected while the voltage across the resonant capacitor can be considered sinusoidal even when the diode is directly biased. Values of $\mathrm{Q}_{\mathrm{E} i}$ around two (or slightly higher) can be considered good options. In fact, $\mathrm{Q}_{\mathrm{E}_{\mathrm{i}} \mathrm{i}}$ can be designed to be lower than two (as in Fig. 8a or Fig. 8b). Nevertheless, in such a case, the voltage is excessively distorted and the behavior of the system cannot be predicted by the proposed equations.

With (28), (40), (46) and (47), equation (64) can be rewritten as:

$$
\mathrm{Q}_{\mathrm{E}_{-} \mathrm{i}}=\frac{1}{\pi^{2}} \cdot \frac{\lambda_{\mathrm{i}}-1}{\lambda_{\mathrm{i}}} \cdot \frac{1}{\left(\mu_{\mathrm{i}}-\mathrm{v}_{\text {knee }}\right) \cdot \Gamma_{\mathrm{i}}},
$$

which will be used in the design guideline.

The calculation of the precise values of $L_{i}$ and $C_{i}$ should be made as follows (see Fig. 9). First of all, the value of $v_{\text {knee }}$ can be calculated using (47). With $v_{\text {knee }}$ and the number of cells, $\mathrm{n}_{\text {cell }}$, the value of $\mu_{\mathrm{i}}$ can be then obtained from (46). Choosing a reasonable value for the conduction angle $\Delta \varphi_{\mathrm{c}}$ (i.e., around $30^{\circ}$ ), and with $\mu_{\mathrm{i}}$, it is possible to obtain the value of the turns ratio of the transformers, $r_{t r \_}$, by means of equations (39), (44) and (45). In Fig. 6, equation (39) is graphically represented: the conduction angle is depicted as a function of $r_{t r} i$ for different values of $\mathrm{n}_{\text {cell }}$ and $v_{\text {knee }}$ (both define the value of $\mu_{\mathrm{i}}$ ). Equation (44), along with $\mathrm{r}_{\mathrm{tr}_{-} \mathrm{i}}$ and $\mu_{\mathrm{i}}$, can be used to obtain the value of $\varphi_{\text {ini }}$ and, consequently, the value of $\varphi_{\text {end }}$

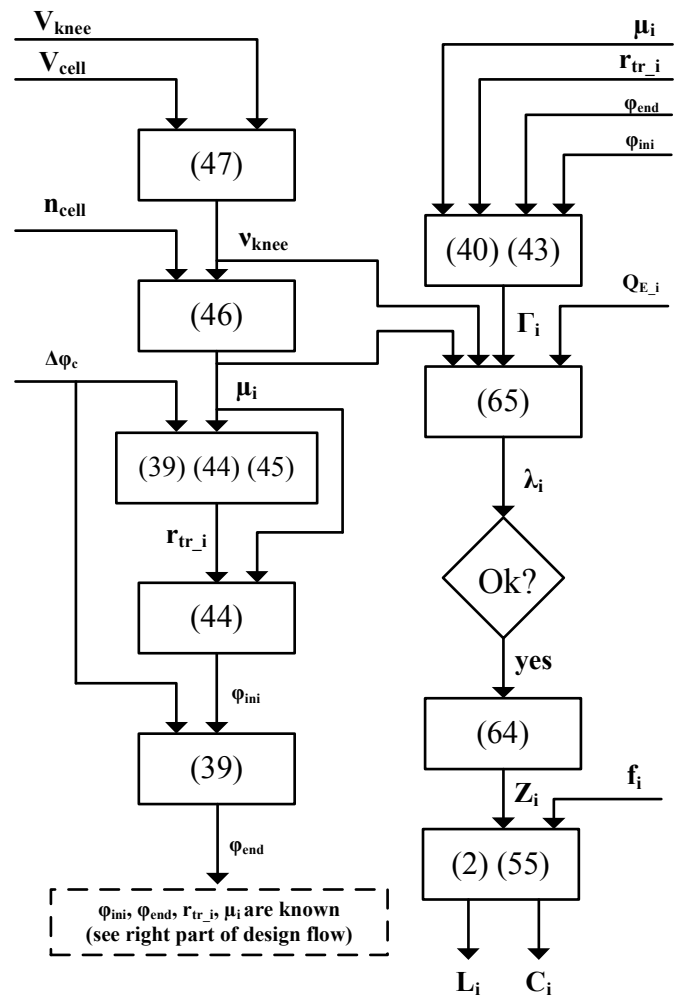

Fig. 9. Design flow chart. according to the chosen value of $\Delta \varphi_{\mathrm{c}} . \Gamma_{\mathrm{i}}$ can be calculated using $\varphi_{\text {ini }}, \varphi_{\text {end }}, r_{t_{-}-i}, \mu_{i}$ and equations (40) and (43). This has been graphically represented in Fig. 7. As has been explained, the value of $\mathrm{Q}_{\mathrm{E} i \mathrm{i}}$ should be high enough in order to assure the proper operation of the resonant traps (as can be seen in Fig. 8, any value of $\mathrm{Q}_{\mathrm{E}_{\_} \mathrm{i}}$ higher than 2 will lead to satisfactory results). Therefore, once $\Gamma_{\mathrm{i}}$ is obtained, equation (65) can be used to determine the minimum value of $\lambda_{i}$ for the chosen value of $Q_{E_{-} i}$. This minimum value of $\lambda_{\mathrm{i}}$ (see equation (28)), should be lower than the value of $\lambda_{\mathrm{i}}$ presented by any of the transformers of the traps once they are built. $I_{\text {cell_i_max }}$, the maximum average equalizing current, is a parameter defined by the designer. Therefore, if the value of $\lambda_{\mathrm{i}}$ is satisfactory (i.e., low enough), then equation (64) can be used to obtained the value of $\mathrm{Z}_{\mathrm{i}}$ according to the chosen value of $\mathrm{Q}_{\mathrm{E} i}$. With $\mathrm{Z}_{\mathrm{i}}$ (equation (55)) and $\mathrm{f}_{\mathrm{i}}$ (its calculation was presented in section IV.A), it is possible to obtain the required values of $\mathrm{L}_{\mathrm{i}}$ and $\mathrm{C}_{\mathrm{i}}$.

\section{Design of the magnetics}

The switching frequency of the proposed system is variable but, ideally, each inductor is going to withstand appreciable voltage only at a frequency equal to the resonant frequency of the trap it belongs to. When the switching frequency of the system is different from the resonant frequency of a trap, the voltage across that trap is almost zero and, consequently, its inductor current is almost zero as well. This means that each inductor does not have to be designed for the whole frequency range, but only for the resonant frequency of its trap [36]. Hence, its design can be optimized and tuned for that frequency, reducing its losses and optimizing the overall design.

Regarding the design parameters, the maximum current, needed for designing a saturation-free transformer, and the ac current, needed for calculating the core losses, can be obtained from the equations presented in section III. The rms current through primary and secondary side of the transformer, needed to calculate the conduction losses, can be obtained also from section III. Finally, the required inductance and the turns ratio have been obtained in section IV.B.

\section{EXPERIMENTAL RESULTS}

A prototype has been built following the design guideline and with the purpose of validating the proposed topology. It has been designed for a pack of four cells connected in series. The switching frequency range is 100 $\mathrm{kHz}-215 \mathrm{kHz}$ considering tolerances of $7.5 \%$ in both, inductors and capacitors (see Table 2). The value of each resonant frequency $f_{i}$ has been obtained according to the design process described in section IV.A. The value of $v_{\text {knee }}$ is around 0.2 ; therefore, $\mu_{\mathrm{i}}$ is 0.3 . As can be seen in Fig. 6, for a conduction angle of around $30^{\circ}$, the required

Table 2. Minimum, nominal and maximum resonant frequency of each trap. Nominal values of inductance and capacitance.

\begin{tabular}{|c|c|c|c|c|c|}
\hline TRAP & $\begin{array}{c}\mathbf{f}_{\text {nom }} \\
(\mathbf{k H z})\end{array}$ & $\begin{array}{c}\mathbf{f}_{\min } \\
(\mathbf{k H z})\end{array}$ & $\begin{array}{c}\mathbf{f}_{\max } \\
(\mathbf{k H z})\end{array}$ & $\mathbf{L}(\boldsymbol{\mu H})$ & $\mathbf{C}(\boldsymbol{\mu F})$ \\
\hline 1 & 109 & 101 & 117 & 6.22 & 0.34 \\
\hline 2 & 134 & 124 & 145 & 5.09 & 0.28 \\
\hline 3 & 164 & 152 & 177 & 4.16 & 0.23 \\
\hline 4 & 200 & 186 & 215 & 3.40 & 0.18 \\
\hline
\end{tabular}


turns ratio is 0.48 . It may advisable to increase this value so that even due to tolerances, the $\mathrm{R}_{\mathrm{DSON}}$ of the MOSFETs, the influence of other traps, etc. the required voltage in the secondary side of the transformer is reached. From Fig. 7 (or the corresponding equations), the resulting value of $\Gamma_{\mathrm{i}}$ is around $2 \cdot 10^{-3}$. As a consequence, the required minimum value of $\lambda_{\mathrm{i}}$ is 1.009 for $\mathrm{Q}_{\mathrm{E}_{\mathrm{i}} \mathrm{i}}=5$ (higher than 2, the minimum value shown in Fig. 8). This value of $\lambda_{\mathrm{i}}$ is lower than the real value that any transformer normally has. Therefore, it is a valid design regarding this issue. $I_{\text {cell_i_max }}$ is defined according to the requirements of the system and its value is $0.1 \mathrm{~A}$. Consequently, the value of $\mathrm{Z}_{\mathrm{i}}$ should be close to 4 . With $Z_{i}$ and $f_{i}$, it is possible to obtain the values of $L_{i}$ and $\mathrm{C}_{\mathrm{i}}$ (see Table 2).

In Fig. 10, the impedance and phase of the string of
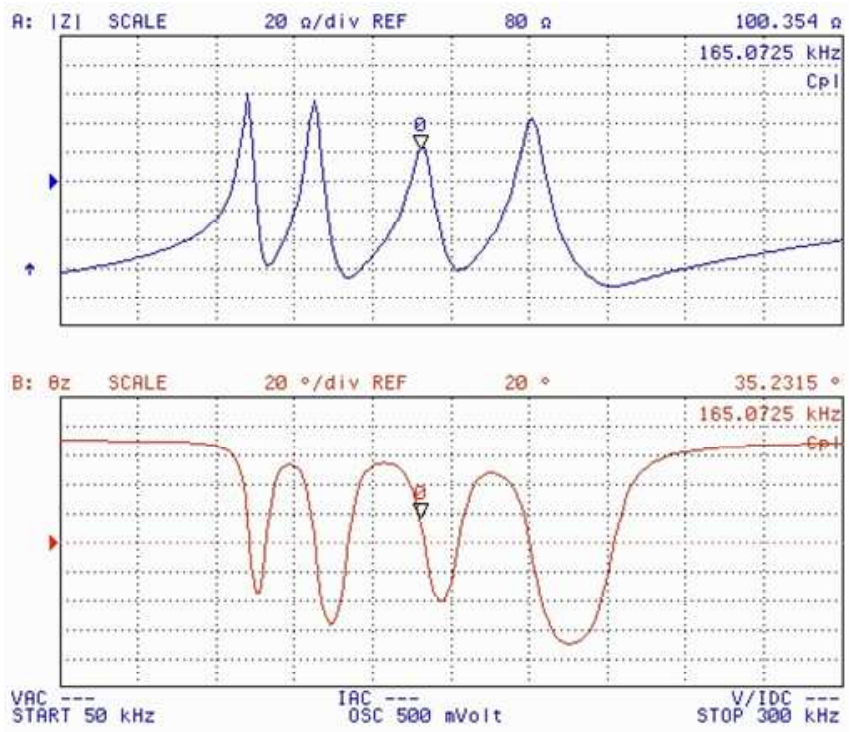

Fig. 10. Frequency sweep of the string of traps (including the additional inductor $\mathrm{L}_{\mathrm{H}}$ )

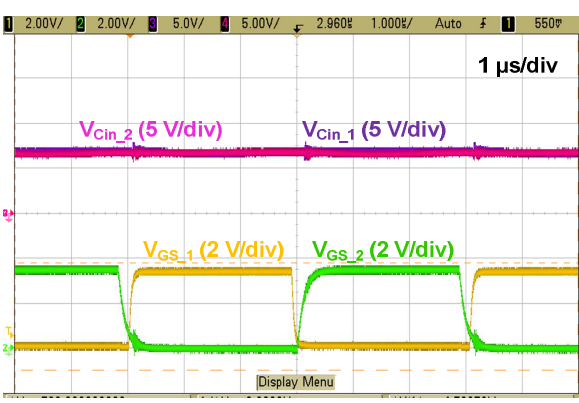

a)

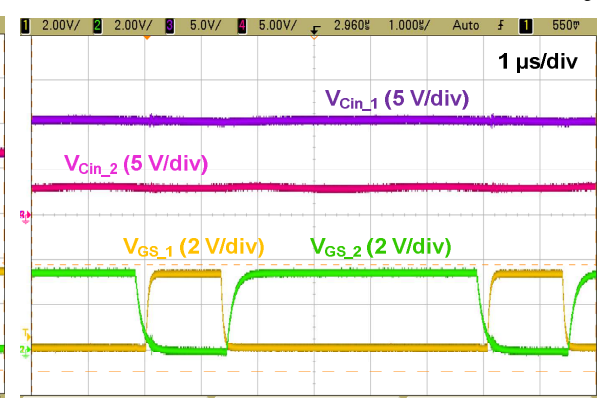

b) traps implemented in the prototype are presented. As can be seen, at each resonant frequency, the overall impedance is defined by the impedance of the trap. Therefore, nearly all the voltage will be withstood by that trap. Harmonic components higher than the first one will be withstood by the traps with a resonant frequency higher than the chosen one and, mainly, by the additional inductor $\mathrm{L}_{\mathrm{H}}$.

In Fig. 11, the gate signals of the MOSFETs are presented. As can be seen, they are complementary and can be easily obtained, which make the control scheme very simple. The voltages of $\mathrm{C}_{\mathrm{in} \_1}$ and $\mathrm{C}_{\mathrm{in} \_2}$ change according to the duty cycle. This variation is the reason why the asymmetrical driving scheme allows the system to control the amplitude of the first harmonic component of the square voltage provided to the string of traps by the half-bridge structure. It should be mentioned that having only two driving signal implies that the control of the system can be easily implemented. The voltage of each cell can be measured using monitoring ICs (such as the LTC6802 or the BQ76PL536) and sent to the controller via serial communication. With those voltages, it can decide which cell should be charged by the equalizer. Then, it only has to generate the two driving signals with the desired switching frequency. When a new cell has to be charged, the system only has to change the switching frequency of the two MOSFETs. In the case of reaching the equalization, the driving signals of both MOSFETs are driven low in order to stop the operation of the converter. It should be also mentioned that the system does not need to sense and control the switching frequency with a feedback loop. The precision obtained with the PWM module of any microcontroller (or with any FPGA) is enough to assure that the switching frequency is within the required tolerances for the proper operation of the system.

In Fig. 12, $\mathrm{V}_{\text {string }}$, the voltage withstood by string of traps, and $V_{\text {trap_3 }}$, the voltage withstood by the chosen trap

Fig. 11. Driving signals of both MOSFETs and voltage of the two input capacitors when a) $\mathrm{D}=50 \%$, b) $\mathrm{D}=75 \%$ and c) $\mathrm{D}=90 \%$.
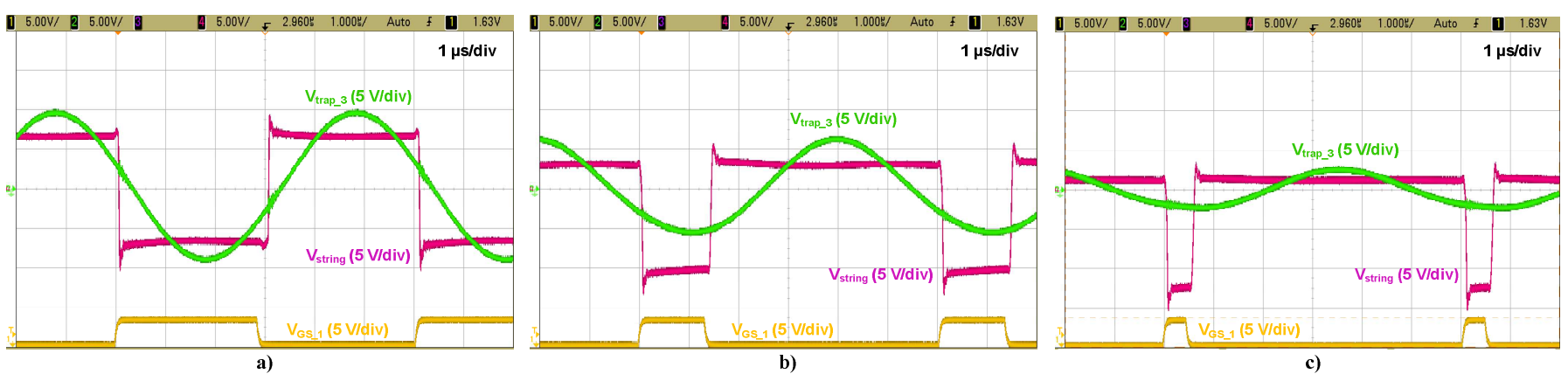

Fig. 12. Driving signal of MOSFET 1, string voltage and trap 3 voltage for a) $\mathrm{D}=50 \%$, b) $\mathrm{D}=75 \%$ and c) $\mathrm{D}=90 \%$ 
(in this case, trap 3), are shown for three different values of $\mathrm{D}$ but for the same value of switching frequency (166 $\mathrm{kHz}$ in order to choose trap 3). As can be seen, the proposed system can determine the amplitude of the voltage withstood by the chosen trap by means of the duty cycle. This implies that the charging process (final voltage of the cell, equalization current, etc.) can be perfectly controlled. Moreover, the negative effects of the leakage inductance or the knee voltage can be overcome. Equalizers based on filters usually use the frequency not only for choosing the cell, but also for controlling the charging process by introducing small variations in this control variable (like in the LLC resonant converter). In the proposed system, the control variable that defines the chosen trap (i.e., the frequency) is different from the control variable that defines the charging process (i.e., the duty cycle). This leads to a higher performance and accuracy.

In Fig. 13, the voltage of the four traps is presented for the four possible switching frequencies (i.e., resonant frequencies). As can be seen, the switching frequency perfectly defines which cell is going to be charged by the
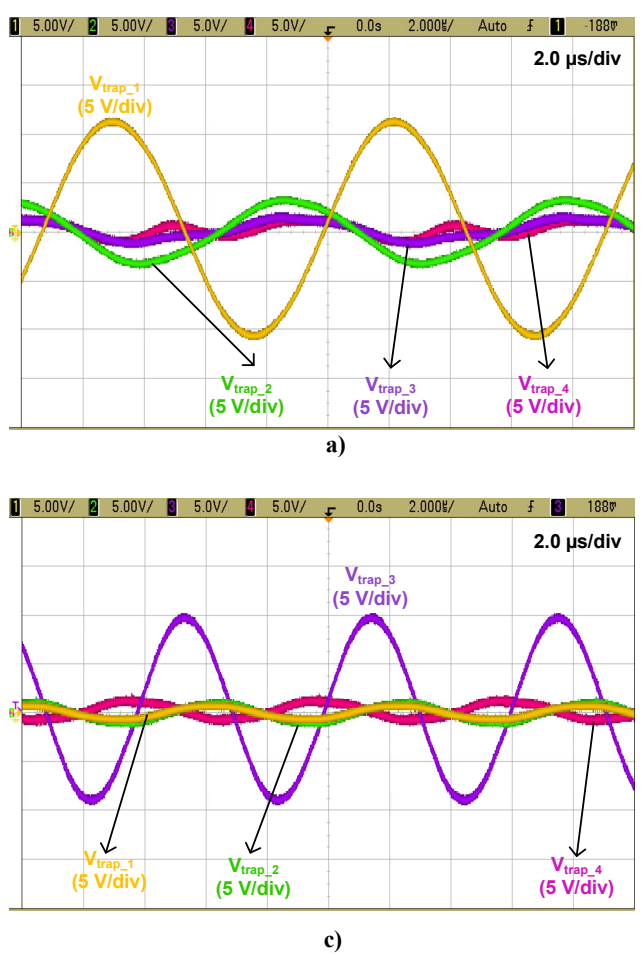

proposed system. The trap whose resonant frequency is equal to the switching frequency of the half-bridge structure withstands nearly all the first harmonic component while the other traps withstand a voltage close to zero. Therefore, the switching frequency represents a valid control variable. As can be seen in Fig. 13b and Fig. $13 \mathrm{c}$, the voltage of the traps which have not be chosen presents a relative phase lag of $180^{\circ}$ due to the inductive behavior of the traps with a resonant frequency higher than the switching frequency and the capacitive behavior of the traps whose resonant frequency is lower than the selected switching frequency. In Fig. 13a and Fig. 13d, the voltages of all the non-chosen traps are in phase because they all have the same behavior (inductive in the case of Fig. 13a and capacitive in the case of Fig. 13d).

In Fig. 14, the secondary-side voltage of the transformer implemented in trap $3\left(\mathrm{~V}_{\mathrm{sec} 3}\right)$, the voltage of cell $3\left(\mathrm{~V}_{\text {cell_3}}\right)$, the equalization current of this cell during a switching period $\left(\mathrm{I}_{\text {cell_ } 3}\right)$ and the voltage applied to trap 3 $\left(\mathrm{V}_{\text {trap } 3} \cdot \mathrm{r}_{\mathrm{tr}}\right.$, referred to the secondary side) are presented for three different duty cycles. As can be seen, the charging process is as described in section III. When $\mathrm{V}_{\text {sec_3 }}$ is equal
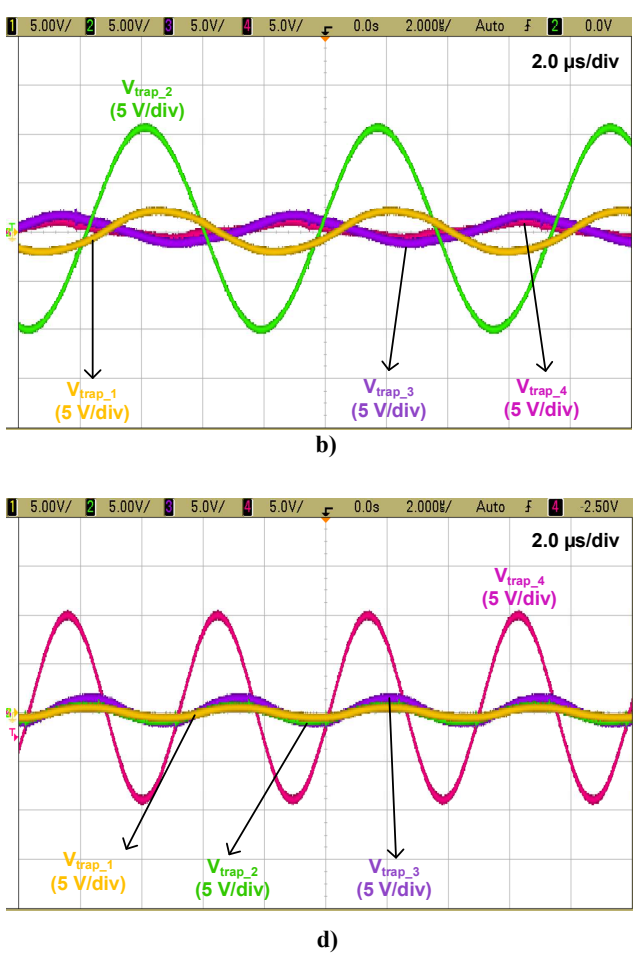

Fig. 13. Voltage of the four traps when the switching frequency is equal to the resonant frequency of a) trap 1, b) trap 2, c) trap 3 and d) trap 4 . In all the cases $\mathrm{D}=50 \%$.
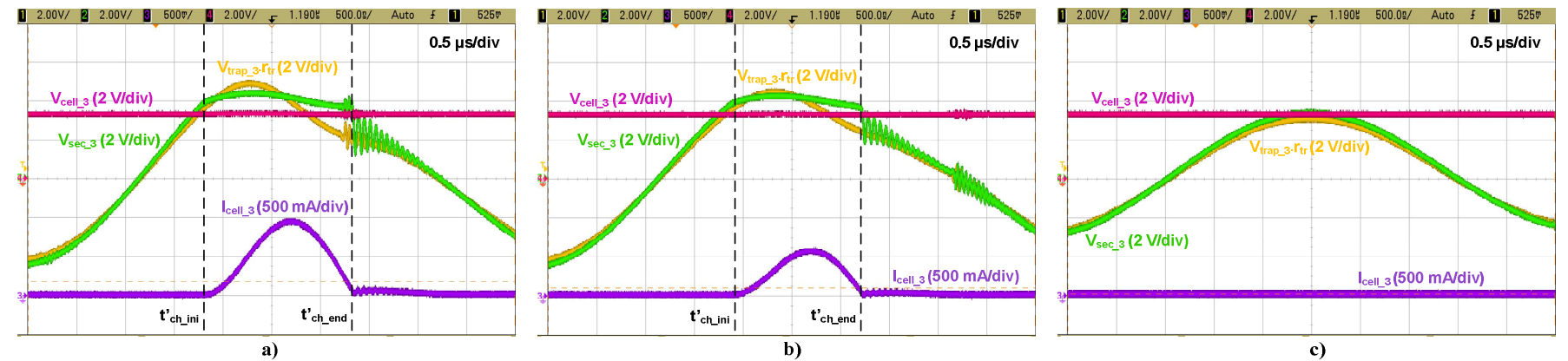

Fig. 14. Equalization current, cell 3 voltage and trap 3 voltage for three different charging rates. a) $D=0.5 ; b) ~ D=0.75 ; c) ~ D=0.90$. 
to the voltage of the cell plus the knee voltage of the rectifier diode, this diode is directly biased and part of the energy stored in the reactive elements of trap 3 is transferred to the cell, which leads to the current waveform (i.e., resonant current) presented in the figure. This current keeps the diode directly biased even when the voltage in the trap (reflected to the secondary side) is lower than the voltage of the cell plus the knee voltage of the diode. When this current naturally reaches zero ( $t_{\text {ch end }}$ ), the diode is reverse biased. Therefore, the diode is operating at zero-current switching.

The purpose of this paper is analyzing the feasibility of the wave-trap concept rather than presenting the equalizer based on the asymmetrical half-bridge converter, which was used only as a proof of concept. As can be seen in Table 1, the wave-trap concept satisfies the purpose of developing equalizers with a reduced number of controlled switches. It should be mentioned that this reduction does not imply losing performance because the charging process is totally under control and it does not imply either increasing the number of other components (i.e., the total number of component is similar to other topologies with the same high performance).

In Fig. 15a, the voltages of cell 3 and cell 4 are shown. For obtaining this figure, capacitors of $1000 \mu \mathrm{F}$ are used instead of real battery cells (in Fig. 15c, Fig. 15d and Fig. 15e, real lithium-ion battery cells are used). In this way, it is possible to verify the results in a shorter time and, moreover, the system faces battery cells with a lower capacity, which involves that more precision is required in

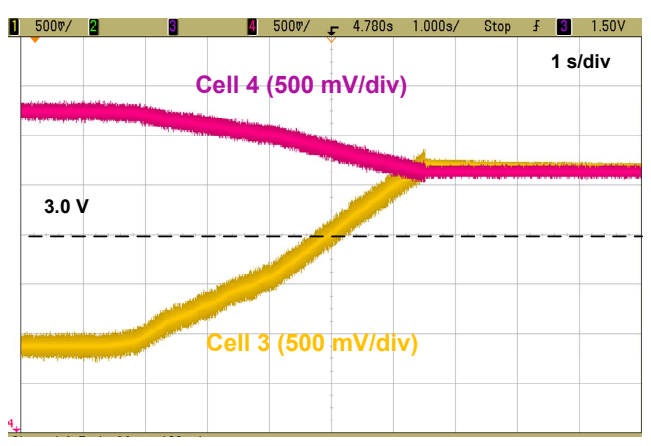

a)
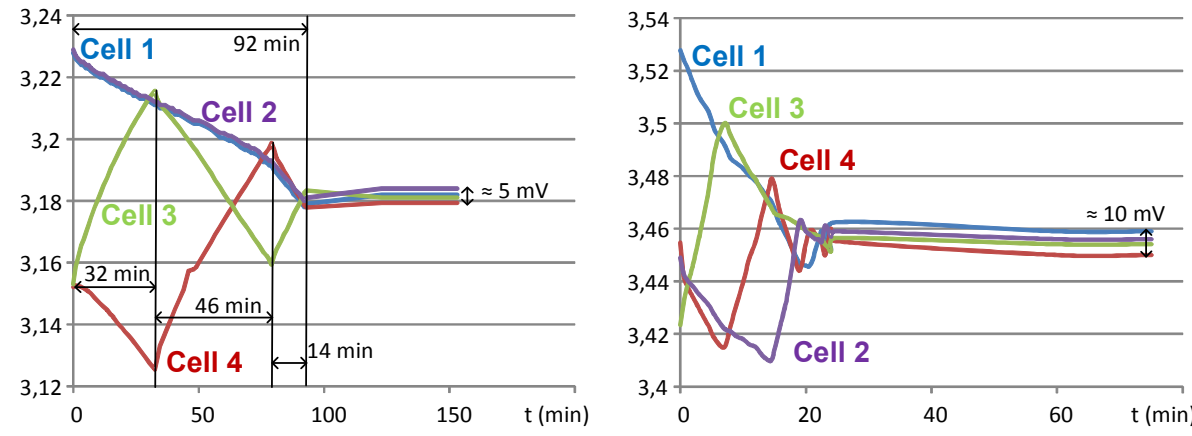

d) order not to exceed the desired voltage. In this case, it can be seen that cell 3 has a voltage of $2.0 \mathrm{~V}$, lower than the voltage of the other cells (around 4.2 V). The proposed equalizer injects energy into cell 3 and raises its voltage to a value close to the voltage of the other cells.

In Fig. 15c, Fig. 15d and Fig. 15e, the proposed equalizer is connected to real 2.5-Ah lithium-ion battery cells. In Fig. 15b, their discharge characteristic, obtained through experimental verification, is provided.

In Fig. 15c, the operation of the proposed equalizer is presented when the voltage of each cell is close to their nominal value (around 3.3 V). At the beginning, the lowest voltage corresponds to cell 3 . The control of the equalizer sets the switching frequency of the half-bridge converter in $164 \mathrm{kHz}$. After 32 minutes, the voltage of cell 3 has reached the value of cell 2 and, therefore, the system changes the switching frequency to $200 \mathrm{kHz}$, in order to charge cell 4 . After 46 minutes, the voltage of cell 4 becomes the highest value and the system changes the frequency to $164 \mathrm{kHz}$ during 14 minutes in order to charge cell 3. After 92 minutes, the voltage of the four cells is within the desired range and the half-bridge converter stops its operation (i.e., both MOSFETs are turned-off). After 150 minutes from the start of the equalization process, the voltage of the four cells is stabilized and the final imbalance is around $5 \mathrm{mV}$. It should be taken into account that using a simple estimation of the OCV of the cells as the criterion for defining which one has to be charged is not an optimum approach. More precise methods can be found in literature [49]-[51]. These

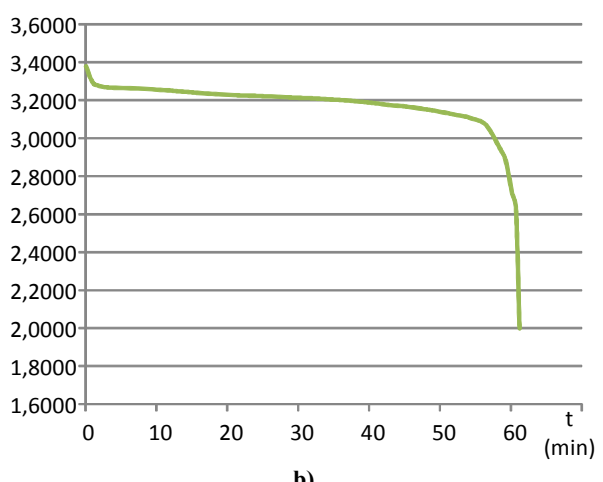

b)

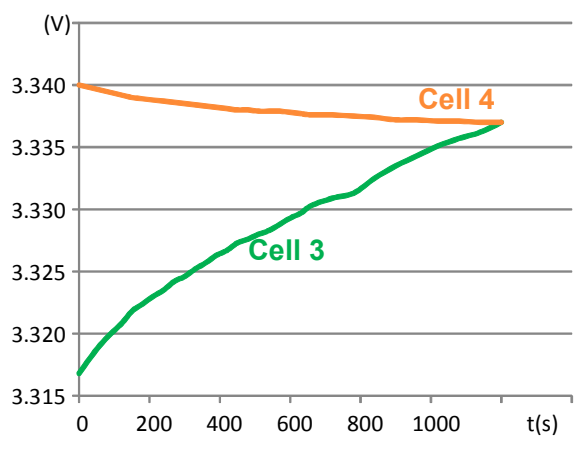

e)

Fig. 15. a) Evolution of the voltages of cell 3 and cell 4 when they are represented by $1000-\mu F$ capacitors; b) Measured cell voltage during discharging; c) Operation of the proposed battery cell equalizer with different starting voltages for each cell around their nominal value; d) Operation of the proposed battery cell equalizer when one of the cells has reached the maximum value; e) Detail of the charging process of one of the cells. 
methods take into account the influence of temperature, uncertainties in models, mapping nonlinearity, aging, etc. and are based on inverse mapping, Coulomb counting or extended Kalman filtering. Nevertheless, the implementation of an optimum Battery Management System (BMS) is out of the scope of this paper and, as a consequence, the simplest approach to the BMS development was chosen.

In Fig. 15d a similar test is carried out, but in this case one of the cells has reached $3.6 \mathrm{~V}$ (i.e. the recommended charging voltage) while cell 2, 3 and 4 have a lower voltage (unbalanced operation of the battery charger). As in the previous case, the cell with the lowest voltage is considered under charged. Due to the region in which battery cells are operated, the equalization process is faster (23 minutes) and the final imbalance, after the stabilization time (around 50 minutes), is close to $10 \mathrm{mV}$. Finally, in Fig. 15e, a detail of the charging process of one of the cells is presented (the stabilization time is not shown).

\section{CONCLUSIONS}

The wave-trap concept has proven to be a valid option for battery-cell equalizers. The switching frequency can be effectively used as the control variable that defines the cell that is going to be charged and, as a consequence, the number of controlled switches in the topology can be reduced. The duty cycle can be used as a different control variable in order to regulate the charging process of the chosen cell. This control variable also allows the system to ignore the influence of certain parameters, such as the leakage inductance or the knee voltage of the rectifier diode, which cannot be totally defined in the design process and may affect the operation of the system. Hence, any equalizer based on the wave-trap concept can be considered as a high-performance one. The ratio between the resonant energy and the energy transferred to the cell should be carefully chosen during the design process in order not to excessively affect the efficiency of the equalizer.

The equalizer presented as a proof of the proposed concept is based on a half-bridge structure, so its number of controlled switches is only two. The number of cells that can be controlled by an equalizer based on this concept is limited by the maximum frequency range. Nevertheless, the use of traps, which have a very high selectivity, increases the number of cells for that given range. For instance, the proposed topology allocates 4 traps in a frequency range of $100 \mathrm{kHz}$ considering tolerances of up to $7.5 \%$ in the components. Any equalizer based on this concept is also highly modular, so the number of cells can be increased without enlarging the frequency range. In that case, the number of controlled switches is increased according to the number of modules connected, but it will be always considerably lower than the number of cells. The use of traps, rather than filters connected to the output of the converter, allows the magnetic components to have an optimized design. Each inductor operates only at the resonant frequency of the trap it belongs to because for the other frequencies its voltage and its current are close to zero. Therefore, their design can be optimized only for one frequency and, as a consequence, size and losses can be strongly reduced.

Finally, the analysis based on the first harmonic component has proven to be perfectly valid as it simplifies the calculation and design guideline of the equalizer while keeping accurate-enough results. This has been validated by means of experimental results.

\section{REFERENCES}

[1] L M. Einhorn, W. Guertlschmid, T. Blochberger, R. Kumpusch, R. Permann, F. V. Conte, C. Kral, and J. Fleig, "A Current Equalization Method for Serially Connected Battery Cells Using a Single Power Converter for Each Cell," Vehicular Technology, IEEE Transactions on, vol. 60, pp. 4227-4237, 2011.

[2] Einhorn, F. V. Conte, C. Kral, and J. Fleig, "Comparison, Selection, and Parameterization of Electrical Battery Models for Automotive Applications," Power Electronics, IEEE Transactions on, vol. 28, pp. 1429-1437, 2013.

[3] K. Chol-Ho, K. Moon-young, P. Hong-sun, and M. Gun-Woo, "A Modularized Two-Stage Charge Equalizer With Cell Selection Switches for Series-Connected Lithium-Ion Battery String in an HEV," Power Electronics, IEEE Transactions on, vol. 27, pp. 3764-3774, 2012.

[4] M. Daowd, N. Omar, P. Van den Bossche, and J. Van Mierlo, "Passive and active battery balancing comparison based on MATLAB simulation," in Vehicle Power and Propulsion Conference (VPPC), 2011 IEEE, 2011, pp. 1-7.

[5] J. Cao, N. Schofield, and A. Emadi, "Battery balancing methods: A comprehensive review," in Vehicle Power and Propulsion Conference, 2008. VPPC '08. IEEE, 2008, pp. 1-6.

[6] T. A. Stuart and Z. Wei, "Fast equalization for large lithium ion batteries," Aerospace and Electronic Systems Magazine, IEEE, vol. 24, pp. 27-31, 2009.

[7] V. L. Teofilo, L. V. Merritt, and R. P. Hollandsworth, "Advanced lithium ion battery charger," Aerospace and Electronic Systems Magazine, IEEE, vol. 12, pp. 30-36, 1997.

[8] C. Pascual and P. T. Krein, "Switched capacitor system for automatic series battery equalization," in Applied Power Electronics Conference and Exposition, 1997. APEC '97 Conference Proceedings 1997., Twelfth Annual, 1997, pp. 848854 vol.2.

[9] J. M. Henry and J. W. Kimball, "Practical Performance Analysis of Complex Switched-Capacitor Converters," Power Electronics, IEEE Transactions on, vol. 26, pp. 127-136, 2011.

[10] C. Speltino, A. Stefanopoulou, and G. Fiengo, "Cell equalization in battery stacks through State Of Charge estimation polling," in American Control Conference (ACC), 2010, 2010, pp. 5050-5055.

[11] A. C. Baughman and M. Ferdowsi, "Double-Tiered Switched-Capacitor Battery Charge Equalization Technique," Industrial Electronics, IEEE Transactions on, vol. 55, pp. 2277$2285,2008$.

[12] K. Sano and H. Fujita, "A resonant switched-capacitor converter for voltage balancing of series-connected capacitors," in Power Electronics and Drive Systems, 2009. PEDS 2009. International Conference on, 2009, pp. 683-688.

[13] Y. Ye, K. W. E. Cheng, and Y. P. B. Yeung, "ZeroCurrent Switching Switched-Capacitor Zero-Voltage-Gap Automatic Equalization System for Series Battery String," Power Electronics, IEEE Transactions on, vol. 27, pp. 3234-3242, 2012. [14] P. Sang-Hyun, K. Tae-Sung, P. Jin-Sik, M. Gun-Woo, and Y. Myung-Joong, "A New Buck-boost Type Battery Equalizer," in Applied Power Electronics Conference and 
Exposition, 2009. APEC 2009. Twenty-Fourth Annual IEEE, 2009, pp. 1246-1250.

[15] K. Nishijima, H. Sakamoto, and K. Harada, "A PWM controlled simple and high performance battery balancing system," in Power Electronics Specialists Conference, 2000. PESC 00. 2000 IEEE 31st Annual, 2000, pp. 517-520 vol.1.

[16] P. Thanh Hai, J. C. Crebier, A. Chureau, A. Collet, and T. Van Nguyen, "Optimized structure for next-to-next balancing of series-connected lithium-ion cells," in Applied Power Electronics Conference and Exposition (APEC), 2011 TwentySixth Annual IEEE, 2011, pp. 1374-1381.

[17] M. J. Isaacson, R. P. Hollandsworth, P. J. Giampaoli, F. A. Linkowsky, A. Salim, and V. L. Teofilo, "Advanced lithium ion battery charger," in Battery Conference on Applications and Advances, 2000. The Fifteenth Annual, 2000, pp. 193-198.

[18] P. A. Cassani and S. S. Williamson, "Design, Testing, and Validation of a Simplified Control Scheme for a Novel PlugIn Hybrid Electric Vehicle Battery Cell Equalizer," Industrial Electronics, IEEE Transactions on, vol. 57, pp. 3956-3962, 2010. [19] K. Tae-Hoon, P. Nam-Ju, K. Rae-Young, and H. DongSeok, "Low cost multiple zero voltage/zero current switching battery equalization circuit with single soft-switching resonant cell," in Vehicle Power and Propulsion Conference (VPPC), 2012 IEEE, 2012, pp. 419-424.

[20] S. Jong-Won, S. Gab-Su, C. Chang-Yoon, and C. BoHyung, "Selective flyback balancing circuit with improved balancing speed for series connected Lithium-ion batteries," in Power Electronics Conference (IPEC), 2010 International, 2010, pp. 1180-1184.

[21] N. H. Kutkut, H. L. N. Wiegman, D. M. Divan, and D. W. Novotny, "Design considerations for charge equalization of an electric vehicle battery system," Industry Applications, IEEE Transactions on, vol. 35, pp. 28-35, 1999.

[22] P. Sang-Hyun, P. Ki-Bum, K. Hyoung-Suk, M. GunWoo, and Y. Myung-Joong, "Single-Magnetic Cell-to-Cell Charge Equalization Converter With Reduced Number of Transformer Windings," Power Electronics, IEEE Transactions on, vol. 27, pp. 2900-2911, 2012.

[23] N. H. Kutkut, D. M. Divan, and D. W. Novotny, "Charge equalization for series connected battery strings," in Industry Applications Society Annual Meeting, 1994., Conference Record of the 1994 IEEE, 1994, pp. 1008-1015 vol.2. [24] Y. C. Hsieh, J. L. Wu, and X. H. Chen, "Class-E-based charge-equalisation circuit for battery cells," Power Electronics, IET, vol. 5, pp. 978-983, 2012.

[25] P. Hong-sun, K. Chong-Eun, K. Chol-Ho, M. GunWoo, and L. Joong-Hui, "A Modularized Charge Equalizer for an HEV Lithium-Ion Battery String," Industrial Electronics, IEEE Transactions on, vol. 56, pp. 1464-1476, 2009.

[26] L. Siqi, C. C. Mi, and Z. Mengyang, "A HighEfficiency Active Battery-Balancing Circuit Using Multiwinding Transformer," Industry Applications, IEEE Transactions on, vol. 49, pp. 198-207, 2013.

[27] M. Einhorn, W. Roessler, and J. Fleig, "Improved Performance of Serially Connected Li-Ion Batteries With Active Cell Balancing in Electric Vehicles," Vehicular Technology, IEEE Transactions on, vol. 60, pp. 2448-2457, 2011.

[28] C. Karnjanapiboon, K. Jirasereeamornkul, and V. Monyakul, "High efficiency battery management system for serially connected battery string," in Industrial Electronics, 2009. ISIE 2009. IEEE International Symposium on, 2009, pp. 15041509.

[29] K. Chol-Ho, K. Moon-Young, and M. Gun-Woo, "A Modularized Charge Equalizer Using a Battery Monitoring IC for Series-Connected Li-Ion Battery Strings in Electric Vehicles,"
Power Electronics, IEEE Transactions on, vol. 28, pp. 37793787, 2013.

[30] Y.-S. Lee and C. Ming-Wang, "Intelligent control battery equalization for series connected lithium-ion battery strings," Industrial Electronics, IEEE Transactions on, vol. 52, pp. 1297-1307, 2005.

[31] M. Uno and K. Tanaka, "Single-Switch Cell Voltage Equalizer Using Multistacked Buck-Boost Converters Operating in Discontinuous Conduction Mode for Series-Connected Energy Storage Cells," Vehicular Technology, IEEE Transactions on, vol. 60, pp. 3635-3645, 2011.

[32] W. Xuezhe and Z. Bing, "The research of vehicle power Li-ion battery pack balancing method," in Electronic Measurement \& Instruments, 2009. ICEMI '09. 9th International Conference on, 2009, pp. 2-498-2-502.

[33] A. M. Imtiaz, F. H. Khan, and H. Kamath, "A low-cost time shared cell balancing technique for future lithium-ion battery storage system featuring regenerative energy distribution," in Applied Power Electronics Conference and Exposition (APEC), 2011 Twenty-Sixth Annual IEEE, 2011, pp. 792-799.

[34] F. Baronti, G. Fantechi, R. Roncella, and R. Saletti, "High-Efficiency Digitally Controlled Charge Equalizer for Series-Connected Cells Based on Switching Converter and Super-Capacitor," Industrial Informatics, IEEE Transactions on, vol. 9, pp. 1139-1147, 2013.

[35] H. Yi-Hsun, L. Tsorng-Juu, S. M. O. Chen, H. Wan-Yi, and C. Yi-Yuan, "A Novel High-Efficiency Compact-Size LowCost Balancing Method for Series-Connected Battery Applications," Power Electronics, IEEE Transactions on, vol. 28 , pp. 5927-5939, 2013.

[36] Jin-Woong Kim; Jong-Won Shin; Jung-Ik Ha, "Cell balancing control using adjusted filters in flyback converter with single switch," Energy Conversion Congress and Exposition (ECCE), 2013 IEEE, vol., no., pp.287,291, 15-19 Sept. 2013

[37] Low, L.; Batchelor, J.; Heaton, R.; Nongji Chen, "Dual patches microstrip fed antenna with wide bandwidth," Antennas \& Propagation Conference, 2009. LAPC 2009. Loughborough , vol., no., pp.429,432, 16-17 Nov. 2009.

[38] F. Weiyi, F. C. Lee, P. Mattavelli, and H. Daocheng, "A Universal Adaptive Driving Scheme for Synchronous Rectification in LLC Resonant Converters," Power Electronics, IEEE Transactions on, vol. 27, pp. 3775-3781, 2012.

[39] F. Dianbo, L. Ya, F. C. Lee, and X. Ming, "A Novel Driving Scheme for Synchronous Rectifiers in LLC Resonant Converters," Power Electronics, IEEE Transactions on, vol. 24, pp. 1321-1329, 2009.

[40] Kazimierczuk, M.K.; Szaraniec, W., "Analysis of class E low di/dt rectifier with a series inductor," Aerospace and Electronic Systems, IEEE Transactions on , vol.29, no.1, pp.278,287, Jan 1993.

[41] M. Arias, D. G. Lamar, F. F. Linera, D. Balocco, A. A. Diallo, Sebastián, J, "Design of a Soft-Switching Asymmetrical Half-bridge structure as Second Stage of an LED Driver for Street Lighting Application," Power Electronics, IEEE Transactions on, vol. 27, pp. 1608-1621, 2012.

[42] G. Y. Jeong, "High efficiency asymmetrical half-bridge structure using a self-driven synchronous rectifier," Power Electronics, IET, vol. 1, pp. 62-71, 2008.

[43] R. Oruganti, H. Phua Chee, J. T. K. Guan, and C. Liew Ah, "Soft-switched DC/DC converter with PWM control," Power Electronics, IEEE Transactions on, vol. 13, pp. 102-114, 1998.

[44] M. Arias, Fernández Diaz, D. G. Lamar, D. Balocco, A. A. Diallo, Sebastián, J., "High-Efficiency Asymmetrical Halfbridge structure Without Electrolytic Capacitor for Low-Output- 
Voltage AC-DC LED Drivers," Power Electronics, IEEE Transactions on, vol. 28, pp. 2539-2550, 2013.

[45] L. Bor-Ren, Y. Cheng-Chang, and D. Wang, "Analysis, design and implementation of an asymmetrical half-bridge structure," in Industrial Technology, 2005. ICIT 2005. IEEE International Conference on, 2005, pp. 1209-1214.

[46] P. K. Jain, A. St-Martin, and G. Edwards, "Asymmetrical pulse-width-modulated resonant DC/DC converter topologies," Power Electronics, IEEE Transactions on, vol. 11, pp. 413-422, 1996.

[47] M. Arias, M. F. Diaz, D. G. Lamar, F. M. Fernandez Linera, and J. Sebastián, "Small-Signal and Large-Signal Analysis of the Two-Transformer Asymmetrical Half-bridge structure Operating in Continuous Conduction Mode," Power Electronics, IEEE Transactions on, vol. 29, pp. 3547-3562, 2014. [48] X. Xu, A. M. Khambadkone, T. M. Leong, and R. Oruganti, "A 1-MHz Zero-Voltage-Switching Asymmetrical
Half-Bridge DC/DC Converter: Analysis and Design," Power Electronics, IEEE Transactions on, vol. 21, pp. 105-113, 2006.

[49] Einhorn, M.; Roessler, W.; Fleig, J., "Improved Performance of Serially Connected Li-Ion Batteries With Active Cell Balancing in Electric Vehicles," Vehicular Technology, IEEE Transactions on , vol.60, no.6, pp.2448,2457, July 2011.

[50] Lezhang Liu; Le Yi Wang; Ziqiang Chen; Caisheng Wang; Feng Lin; Hongbin Wang, "Integrated System Identification and State-of-Charge Estimation of Battery Systems," Energy Conversion, IEEE Transactions on , vol.28, no.1, pp.12,23, March 2013.

[51] Xiaonan Lu; Kai Sun; Guerrero, J.M.; Vasquez, J.C.; Lipei Huang, "State-of-Charge Balance Using Adaptive Droop Control for Distributed Energy Storage Systems in DC Microgrid Applications," Industrial Electronics, IEEE Transactions on , vol.61, no.6, pp.2804,2815, June 2014 